\title{
The Controlling Influence of Carbon Dioxide.
}

\section{On the Production of Secondary Dormancy in Seeds of Brassica alba following Treatment with Carbon Dioxide, and the Relation of this Phenomenon to the Question of Stimuli in Growth Processes.}

BY

\author{
FRANKLIN KIDD, M.A., D.Sc., \\ Fellow of St. John's College, Cambridge,
}

AND

CYRIL WEST, A.R.C.SC., B.Sc.

With Plate XXIII and five Figures in the Text.

CONTENTS.

§. INTRODUCTION • • • • • • • • • • • • • • 457

2. The Production of Secondary Dormancy in Seeds of Brassica alba • $45^{8}$

3. Changes in the Seed-coat or Embryo of Brassica alba accompanying the Production of Secondary Dormancy . . • . . . . . 465

4. Methods of forcing Germination of Brassica alba Seeds showing Secondary

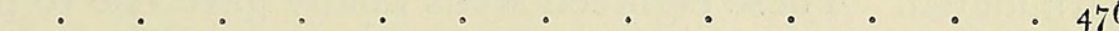

5. Summary • • • • • • • • • • • • • • $44^{83}$

6. Conclusions • • • • • • • • • • • • • . 485

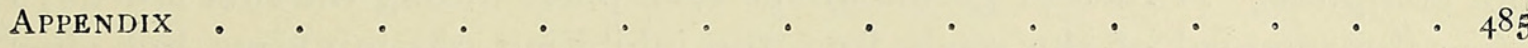

\section{$\S$ I. INTRODUCTION.}

T $\mathrm{N}$ previous papers (Kidd, 1 and 2 ) it has been shown that carbon dioxide in relatively small quantities in the atmosphere inhibits the germination of seeds. The actual percentage of carbon dioxide required to produce inhibition was found to vary with temperature and with oxygen supply. At $3^{\circ}$ centigrade 2 per cent. to 4 per cent. carbon dioxide produced in. hibition, whilst at $20^{\circ}$ centigrade 25 per cent. to 30 per cent. carbon dioxide was required. With 5 per cent. oxygen, 9 per cent. to I 2 per cent. carbon dioxide produced inhibition, but with 20 per cent. oxygen 20 to 25 per cent. carbon dioxide was required (temperature $\mathrm{I} 7^{\circ} \mathrm{C}$.).

In all seeds tested, except those of Brassica alba, germination in the normal way was found to follow the removal of the inhibiting carbon dioxide. In the case of Brassica alba seeds, the dormancy induced by carbon dioxide continued, however, after the removal of the inhibiting

[Annals of Botany, Vol. XXXI. Nos. CXXIII and CXXIV. July and October, 1917.] 
gas-mixtures. This induced dormant condition of White Mustard seeds following as an 'after'-effect of carbon dioxide inhibition is here termed 'secondary dormancy' (cf. Crocker (3), p. II4 et seq.).

Normally, Brassica alba seed germinates quickly and uniformly in twenty hours at ordinary temperatures with a high percentage of germination. ${ }^{1}$ The behaviour of Brassica alba seeds showing secondary dormancy as an 'after'-effect of short $\mathrm{CO}_{2}$-treatment was in striking contrast to this. The typical behaviour of a sample of Brassica alba seed removed from an inhibiting partial pressure of carbon dioxide is shown by the following table :

TABLE I.

$\begin{array}{cc}\begin{array}{c}\text { Number of days after removal from } \\ \text { the inhibiting gas-mixture. }\end{array} & \begin{array}{c}\text { Number of } \\ \text { germinations. }\end{array} \\ 6 & \mathrm{I} 7 \\ 16 & 49 \\ 44 & 73 \\ 68 & 103 \\ 365 & 135 \\ \text { Number of seeds used }=153 . & \\ * 20 \% \mathrm{CO}_{2} ; 20 \% \mathrm{O}_{2} \text { for } \mathrm{I} 9 \text { days. }\end{array}$

In this experiment, which was extended to twelve months, during the whole of which period the seeds lay on damp sand in a moist atmosphere, it is seen that a few seeds are constantly germinating in a sporadic manner. This slow sporadic germination is typical of Brassica alba seeds showing secondary dormancy. After twelve months, in this particular case, eighteen seeds out of an original sample of 153 inhibiting seeds still remained ungerminated. These eighteen seeds finally gave rise to perfect seedlings.

Occasionally it was found that the secondary dormancy produced was not complete. A rush of germinations took place during the first few days after the removal of the seeds from the inhibiting gas-mixtures, but after this period, however, characteristic sporadic germination set in. For example, in ten days $4^{I}$ per cent. of a sample of eighty inhibited seeds had germinated, whilst only 5 per cent. more germinated in the following twenty days.

The object of the work described in the present paper has been to discover, if possible, the controlling causes of this secondary dormancy which follows as an 'after'-effect of carbon dioxide inhibition in the case of Brassica alba.

\section{§2. The Production of Secondary Dormancy in Seeds of BRASSICA ALBA.}

In view of the fact that the degree of secondary dormancy had been observed to vary considerably, a complete series of experiments was conducted in order to determine the optimum gas-mixtures with regard

iThe Brassica alba seeds used in this investigation gave germination tests of $98 \%$ to $100 \%$. 
to carbon dioxide and oxygen for the production of secondary dormancy as an 'after'-effect.

In these experiments an arbitrary period of ten days was allowed before determining the number of seeds showing secondary dormancy. This period was chosen as a result both of our general experience and of specific experiments, to one of which we have already referred. In result it was found that a high percentage of seeds showing prolonged secondary dormancy could only be obtained under quite limited conditions.

\section{OXYGEN.}

The following experiments deal with the question as to how far the degree of secondary dormancy is influenced by the concentration of oxygen used during the primary period of inhibition. Two series were conducted :

TABLE II.

Effect of various Partial Pressures of Oxygen $(25$ per cent. Carbon Dioxide present) on the Production of Secondary Dormancy in Seeds of Brassica alba.

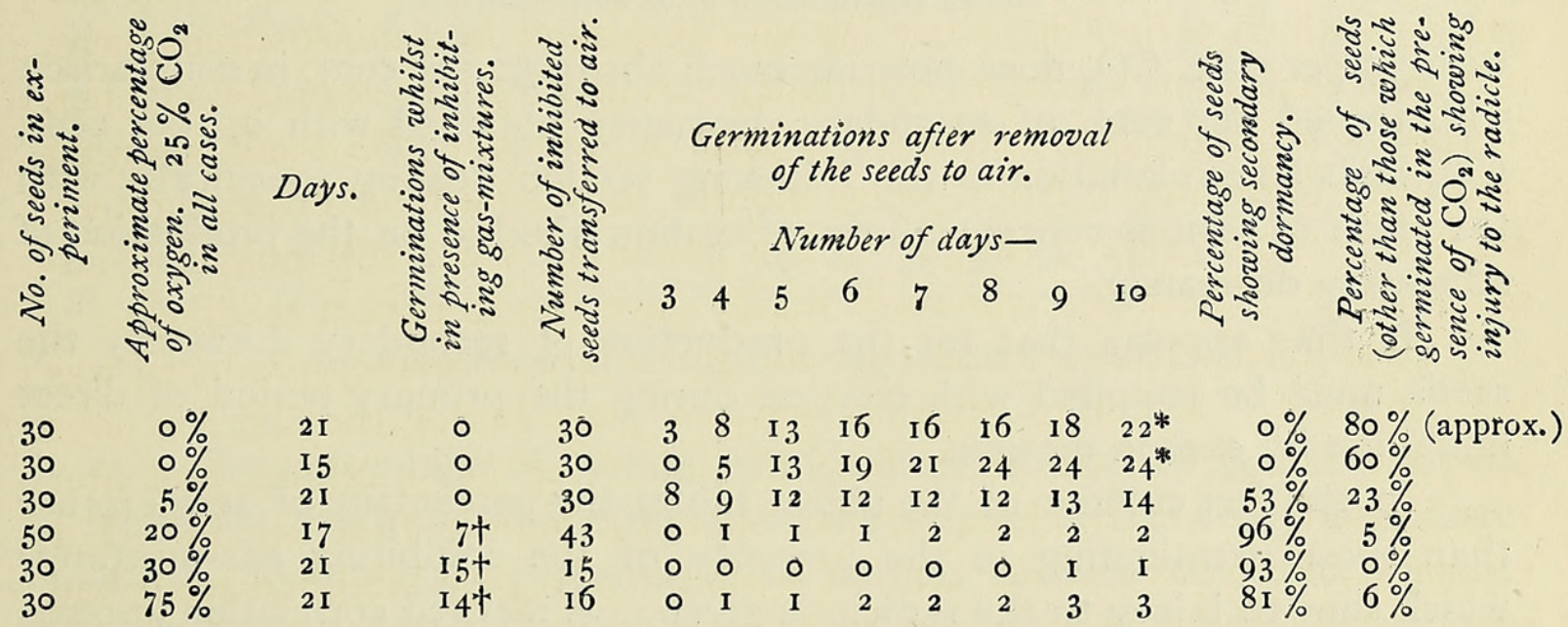

Mean temperature of laboratory during inhibition period, $\mathrm{I} 5^{\mathrm{n}} \mathrm{C}$.

$\uparrow$ All showing injury to radicle.

with 25 per cent. carbon dioxide present (Table II); and with 35 per cent. carbon dioxide present (Table III). The amount of oxygen present was found to influence the degree of secondary dormancy. Thus in Table II it is seen that with concentrations of oxygen below 20 per cent., the percentage of seeds showing secondary dormancy decreases with the fall of oxygen. With 20 per cent. oxygen present 96 per cent. of the seeds show secondary dormancy, and higher concentrations of oxygen have little effect, the percentage of seeds showing secondary dormancy remaining high. 
In Table III the results are of a similar nature. In the absence of oxygen no secondary dormancy is obtained, whereas with I 5 per cent. or 30 per cent. oxygen present approximately half the seeds exhibit secondary dormancy. The fact that the amount of secondary dormancy obtained

\section{TABLE III.}

Effect of various Partial Pressures of Oxygen $(35$ per cent. Carbon Dioxide present) on the Production of Secondary Dormancy in Seeds of Brassica alba.
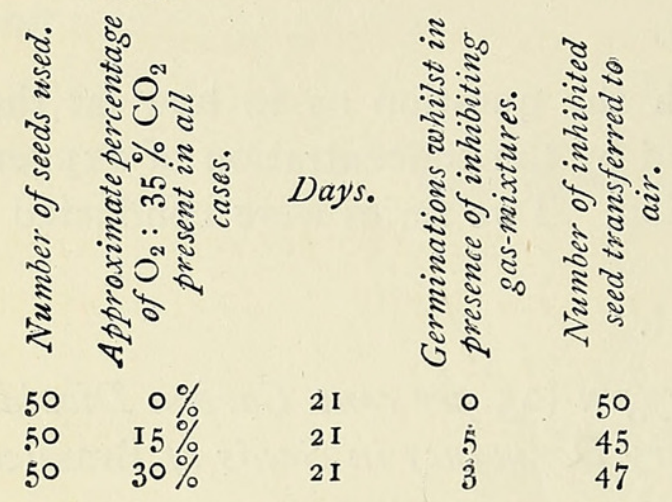

Germinations after reinoval of seeds to air.

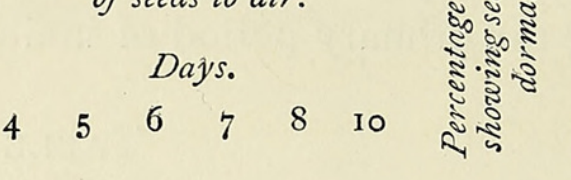

I' $23 \quad 27 \quad 30 \quad 32 \quad 35^{*}$

$\begin{array}{llllll}4 & 13 & 15 & 17 & 22 & 24\end{array}$

$\begin{array}{llllll}4 & \text { I } & 13 & \text { I } 3 & \text { I } 7 & 22\end{array}$

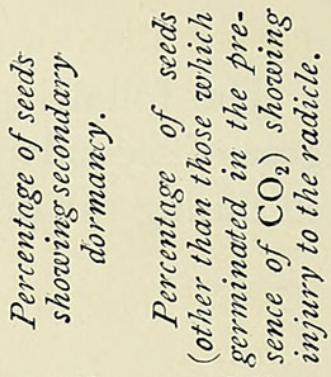

$\circ \% \%$
$53 \%$ $78 \%$
$10 \%$
$4 \%$

Mean temperature of laboratory during inhibition period, $13^{\circ} \mathrm{C}$.

* The I 5 ungerminated seeds were dead.

with 3.5 per cent. $\mathrm{CO}_{2}$ does not rise much above 50 per cent. in comparison with the 96 per cent. of secondary dormancy obtained with 2.5 per cent. $\mathrm{CO}_{2}$ finds an explanation in the following section dealing specifically with the effect of various concentrations of carbon dioxide on the production of secondary dormancy.

It thus appears that for the production of secondary dormancy the seeds must be supplied with oxygen during the primary period of direct inhibition by carbon dioxide.

In the last column of the above tables the percentage of seeds (other than those germinating in the presence of the inhibiting gas-mixtures) which showed injury to the radicle is given. A marked correlation appears between the injury to the radicle and percentage of seeds showing secondary dormancy: the greater the injury the less the amount of secondary dormancy produced.

Where secondary dormancy is almost complete, the percentage of seeds showing injury is practically wil. In fact it may be said that any seed which after ten days in air shows typical secondary dormancy (in other words, is practically indistinguishable from a newly swollen normal seed) is certainly uninjured with regard to the radicle. The condition with regard to injury or non-injury of the seeds showing secondary dormancy was examined by the removal of the seed-coats, a treatment which, as pointed out in a previous paper (Kidd, 1, p. 4I6), will cause germination at any time during the period of secondary dormancy. 


\section{CARBON DiOXIDE.}

The following experiments deal with the question as to how far the degree of secondary dormancy is influenced by the concentration of carbon dioxide used during the primary period of inhibition.

These experiments were conducted in three series: with 20 per cent. oxygen present, with Io per cent. oxygen present, and with $\circ$ per cent. oxygen present.

Table IV gives the results of the series of experiments with a range of carbon dioxide concentrations, 20 per cent. oxygen being present in all

\section{TABLE IV.}

Effect of various Partial Pressures of Carbon Dioxide $(20$ per cent. Oxygen present) on the Production of Secondary Dormancy in Seeds of Brassica alba.

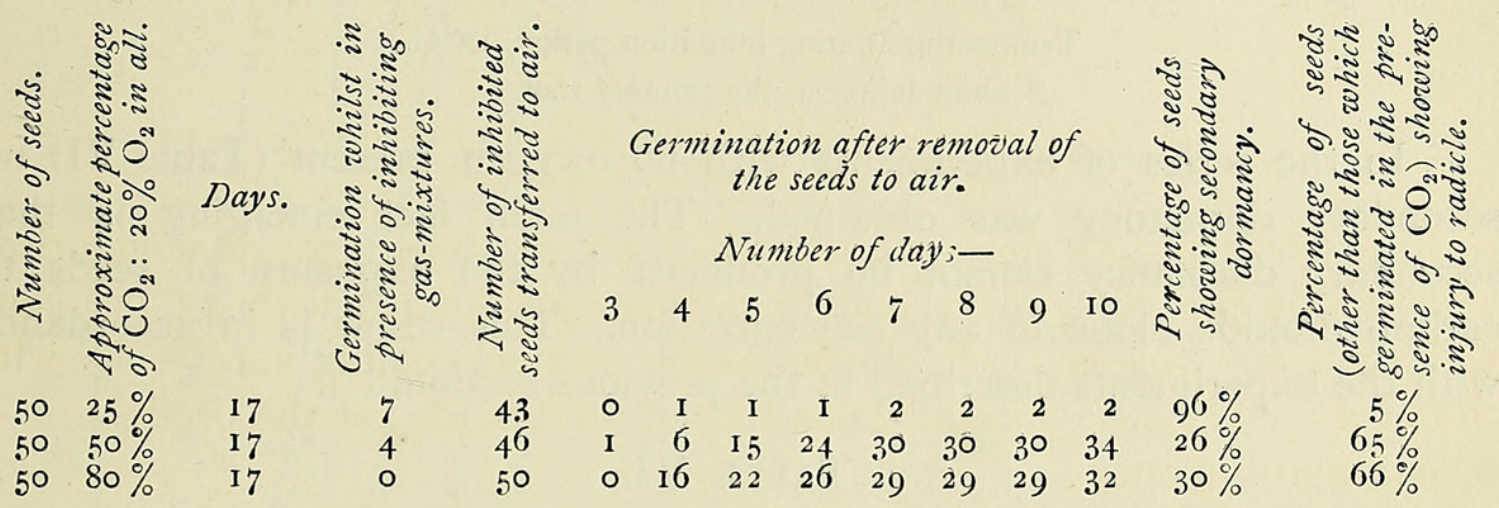

Mean temperature of laboratory during inhibition period, $15^{\circ} \mathrm{C}$.

cases. The percentage of carbon dioxide used during the primary period of inhibition has a marked effect upon the degree of secondary dormancy obtained. When high percentages of carbon dioxide are used for the production of primary inhibition, the percentage of seeds showing secondary dormancy as an 'after'-effect is small and at the same time a considerable percentage of seedlings show injury to the radicle. The optimum treatment for the production of secondary dormancy in these experiments, in which the concentration of oxygen present amounts to 20 per cent., is with 25 per cent. carbon dioxide.

The results of the experiments with a range of carbon dioxide concentrations and Io per cent. oxygen present in all cases (Table V) are of a similar nature. Following the treatment with the higher percentages of carbon dioxide injury occurs and the number of seeds showing secondary dormancy is small. Both the maximum 'after'-effect of secondary dormancy ( 73 per cent.) and the minimum percentage of injury ( 2 per cent.) occur in these experiments after treatment with Io per cent. carbon dioxide. 
TABLE V.

Effect of various Partial Pressures of Carbon Dioxide (Io per cent. Oxygen present) on the Production of Secondary Dormancy in Seeds of Brassica alba.

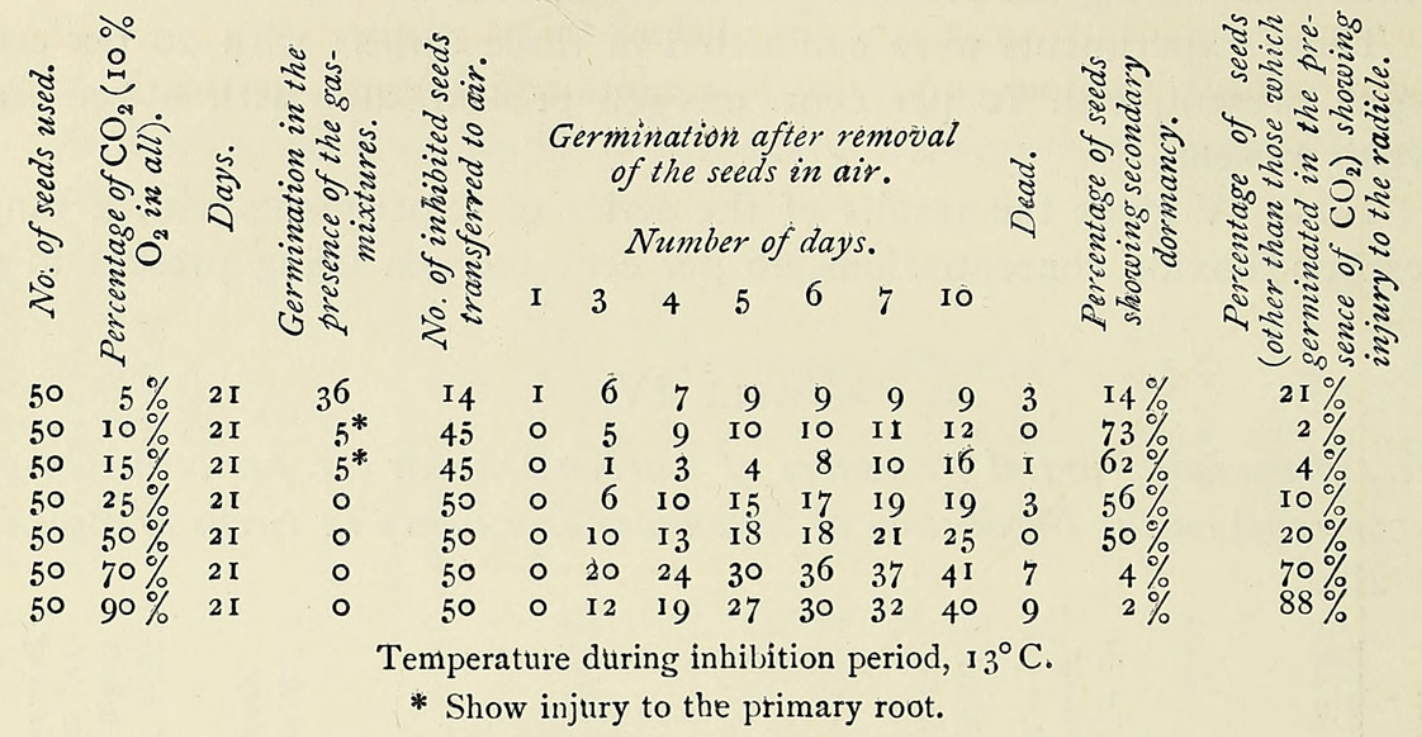

In the series of experiments with no oxygen present (Table VI) no secondary dormancy was obtained. The main fact emerging is that secondary dormancy cannot be produced by the exposure of seeds to carbon dioxide alone in any concentration. This result is in accordance with the experiments described in the previous section.

\section{TABLE Vİ.}

Effect of various Partial Pressures of Carbon Dioxide (no Oxygen present) on the Production of Secondary Dormancy in Seeds of Brassica alba.
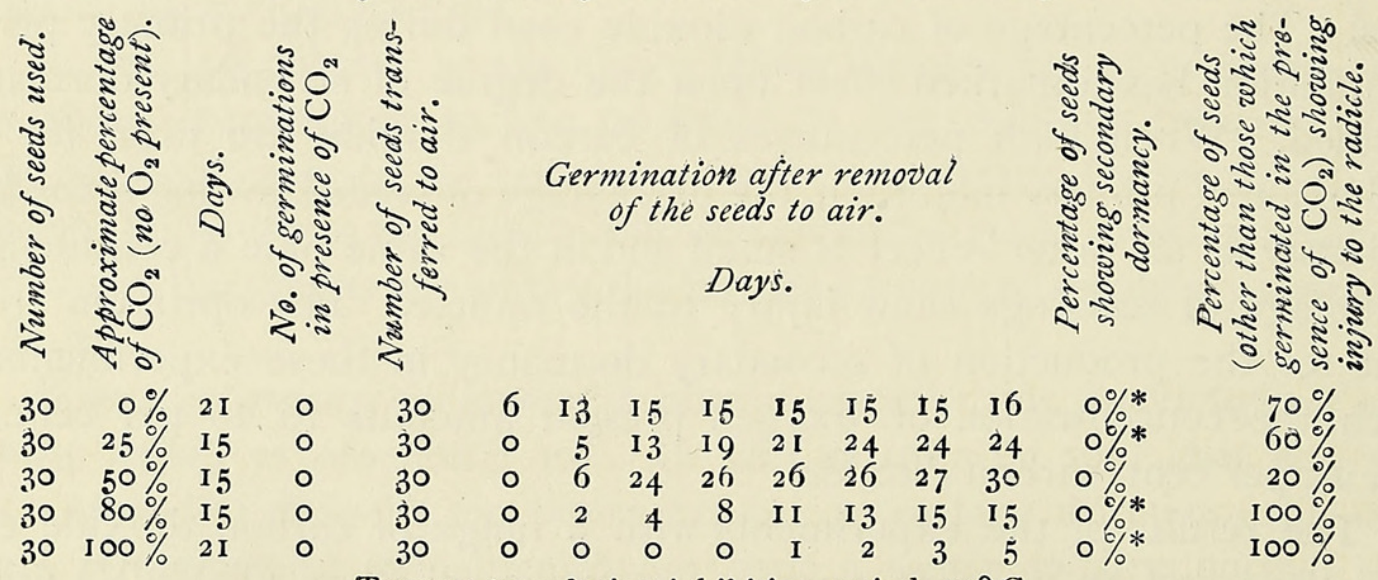

Temperature during inhibition period, $13^{\circ} \mathrm{C}$.

* All seeds still ungerminated after Io days in air were either dead or so badly injured with regard to the radicle that they finally decayed.

Marked injury to the radicle occurs in these experiments in the absence of oxygen, and a correlation between subsequent germination and injury to the radicle thus appears again. 
With the intermediate concentrations of carbon dioxide, following which the injury occurring is much less, ${ }^{1}$ the correlation between germination and injury is not so great. Thus, following 50 per cent. carbon dioxide in the absence of oxygen, only 20 per cent. of the seeds showed visible injury to the radicle although all germinated and none showed secondary dormancy. Nevertheless, the conditions in the absence of oxygen are undoubtedly injurious, and do, if maintained, result in death. If the

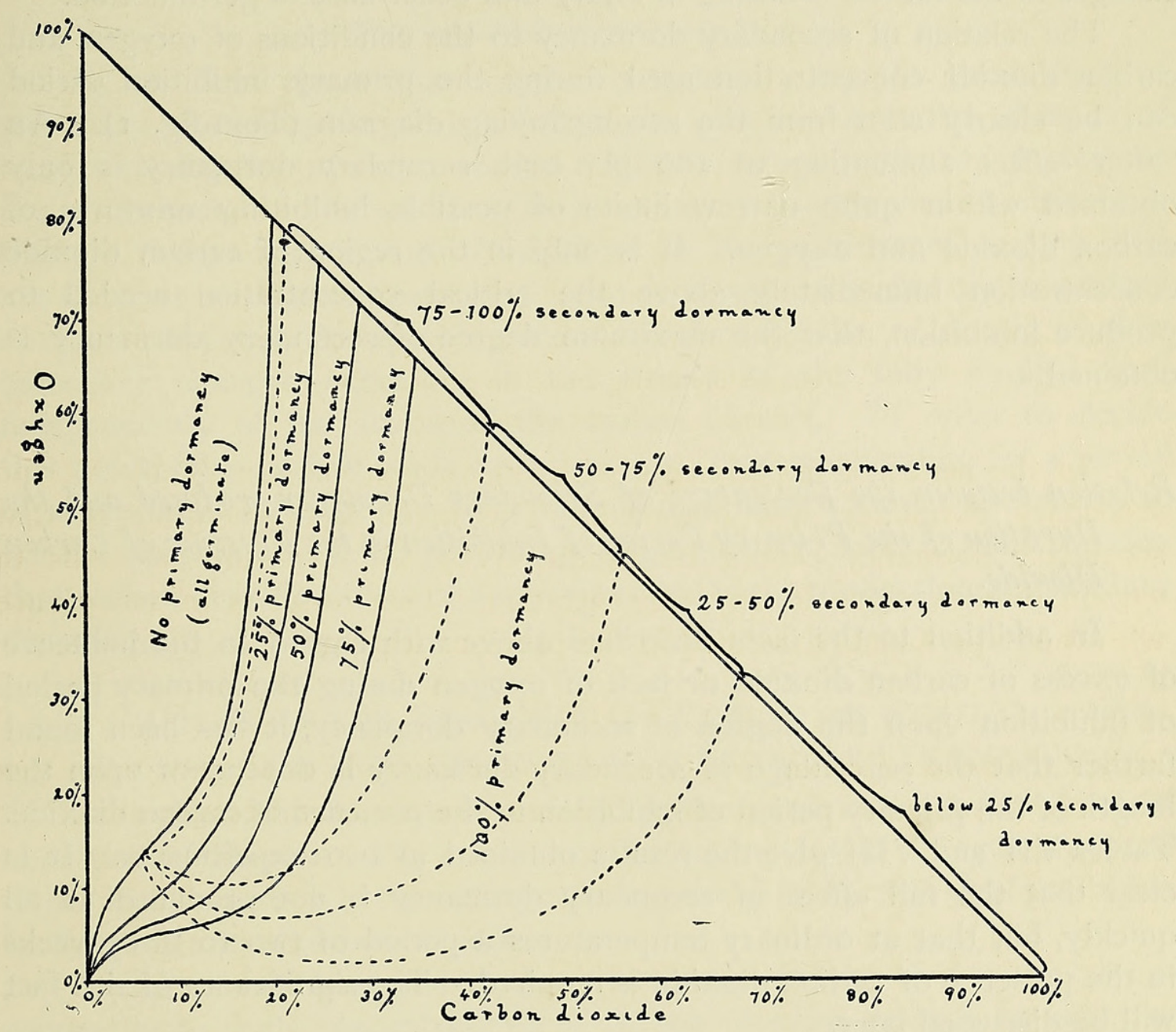

TEXT-FIG. I.

internal reactions which cause injury in the embryo are also those which are responsible for germination, as the correlation observed in the above experiments indicates, this particular case is of interest in that it shows that these internal changes initiate growth in their early stages before they have proceeded far enough to produce visible injury and cell-death.

Summing up the results of these experiments dealing with the conditions necessary for the production of secondary dormancy in Brassica

1 This in itself is remarkable, and is to be attributed to an effect of carbon dioxide in depressing anaerobic processes which give rise to toxic products (cf. Kidd, 4). 
alba seeds, it appears (i) that the phenomenon does not occur if oxygen has not been present during the primary period of inhibition or if carbon dioxide has been used in too high a concentration; (ii) that those conditions during the primary period of inhibition which prevent the subsequent occurrence of secondary dormancy, are found at the same time to exercise an injurious effect upon the radicle which is visible when the seeds subsequently germinate, and that a correlation exists therefore between internal changes in the radicle resulting in injury and occurrence of germination.

The relation of secondary dormancy to the conditions of oxygen and carbon dioxide concentration used during the primary inhibition period can be clearly seen from the accompanying diagram (Text-fig. I). An 'after'-effect amounting to Ico per cent. secondary dormancy is only obtained within quite narrow limits of possible inhibiting mixtures of carbon dioxide and oxygen. It is only in the region of carbon dioxide concentration immediately above the critical concentration needed to produce inhibition, that the maximum degree of secondary dormancy is obtained.

Relation between the Percentage of Secondary Dormancy produced and the Duration of the Primary Period of Inhibition in the Presence of Carbon Dioxide.

In addition to the facts described above with regard to the influence of excess of carbon dioxide or lack of oxygen during the primary period of inhibition upon the degree of secondary dormancy, it has been found further that the percentage of secondary dormancy is dependent upon the length of the primary period of inhibition in the presence of carbon dioxide. Tables VII and VIII give the results obtained in two experiments. It is clear that the full effect of secondary dormancy is not produced at all quickly, but that at ordinary temperatures a period of two to three weeks in the presence of carbon dioxide is required. The significance of this fact will be discussed later.

\section{TABLE VII.}

Time Factor in the Production of Secondary Dormancy.

Number of days in the gas. mixture $\left(20 \% \mathrm{CO}_{2}=\right.$ $16 \%\left(\mathrm{U}_{2}\right)$.

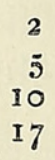

Germinations Io days after removal from the inhibiting gas-mixture.

$$
\begin{array}{r}
100 \% \\
66 \% \\
57 \% \\
17 \%
\end{array}
$$

Approximate percentage of secondary dormancy.

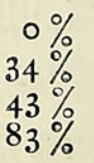

30 seeds in each experiment. Mean temperature of laboratory, $12.5^{\circ} \mathrm{C}$. (in the dark). 
TABLE VIII.

Time Factor in the Production of Secondary Dormancy.

Number of days in the gas-
mixture $\left(30 \% \mathrm{CO}_{2}=\right.$
I $\left.4 \% \mathrm{O}_{2}\right)$.
I
3
4
8
I 2

Germinations ro days after removal from the inhibiting gas-mixture.

$$
\begin{array}{r}
100 \% \\
60 \% \\
40 \% \\
40 \% \\
6 \%
\end{array}
$$

Mean temperature of laboratory, $14^{\circ} \mathrm{C}$.
Approximate percentage of secondary dormancy.

$0 \%$
$40 \%$
$60 \%$
$60 \%$
$94 \%$

It has been shown that oxygen is necessary for the production of secondary dormancy in seeds of Brassica alba, since in the absence of oxygen during the primary period of inhibition injury occurs which prevents the phenomenon. Carbon dioxide is necessary because in the absence of this gas the primary period of inhibition in the presence of oxygen does not occur at normal temperatures. But it is not clear whether secondary dormancy is due to the specific action of carbon dioxide or simply to slow secondary changes occurring in the tissues of the fully swollen seed independently of the action of the carbon dioxide. In order to decide this point, fully-swollen seeds were prevented from germinating for a period of seven days by exposure to a subminimal temperature. On return to normal temperatures a full percentage of germination resulted, thus showing that carbon dioxide exercises a specific action in the production of secondary dormancy.

\section{\$3. Changes in the Seed-coat or Embryo of Brassica alba accompanying the Production of Secondary Dormancy.}

It is clear that the causes underlying the persistence of the dormant condition of Brassica alba seeds must be looked for in changes produced either in the testa or in the embryo during the primary period of inhibition in the presence of carbon dioxide.

It has already been shown that when such changes, due to the lack of oxygen or to toxic concentrations of carbon dioxide, amount to injury to the radicle, secondary dormancy does not occur.

It is convenient at this point to analyse, on the lines of previous research work on dormancy in seeds, the possible causes controlling the phenomenon of secondary dormancy in uninjured seeds of Brassica alba.

A. A change in the seed-coat during the period of primary inhibition in the inhibiting gas-mixtures:

(i) Resulting in decreased permeability of the testa to oxygen sufficient to cause the prolonged secondary dormancy observed.

(ii) Resulting in decreased permeability of the testa to carbon dioxide, owing to which the tension of respiratory carbon dioxide in the tissues of the embryo during the period of secondary dormancy does not fall below 
a critical value in relation to oxygen supply and temperature at which germination can take place.

(iii) Resulting in increased mechanical resistance, owing to which either $(a)$ the full swelling of the embryo by physical water uptake to the critical point at which germination and further growth become possible is prevented, or $(b)$ owing to which the radicle is unable to burst its way through the seed-coats by growth although the water supply is not the limiting factor.

B. Changes in the embryo during the period of primary inhibition in the inhibitory gas-mixtures, owing to which the embryo becomes less sensitive to growth conditions; in other words, there is a rise in the threshold value of the necessary growth stimulus, so that the same value in the case of some critical growth condition (e. g. of oxygen supply, $\mathrm{CO}_{2}$ tension, moisture, temperature, hydrogen ion concentration, or other internal factor), which in the case of the untreated seeds was sufficient, although near the critical minimum, to cause germination, becomes subminimal after treatment with carbon dioxide.

\section{Changes in the Permeability of the Seed-coats to Gases.}

In order to test whether any change in the permeability of the testa to gases takes place during the immersion of the seeds in atmospheres of carbon dioxide, direct experiments were carried out. These were conducted in two series. In Series A the permeability of the testa to carbon dioxide was determined, whilst in Series B the object of the experiments was to ascertain the permeability of the seed-coats to oxygen.

Series $A$.

The principle of these experiments was as follows:

A number of fully swollen White Mustard seeds, inhibited and noninhibited respectively, were brought suddenly into an atmosphere of pure $\mathrm{CO}_{2}$; then the rate of $\mathrm{CO}_{2}$ uptake was compared in either case. When no further uptake occurred, the atmosphere of $\mathrm{CO}_{2}$ was quickly replaced by an atmosphere of nitrogen and the rate at which the $\mathrm{CO}_{2}$ escapes was measured.

Fig. 2, $a$, represents the apparatus employed. The seeds are placed in the wide-bore tubes $\mathrm{A}$ and $\mathrm{B}$, which are then connected to the capillary tubes $\mathrm{C}$ and $\mathrm{D}$ by means of rubber connexions as is shown in the diagram. The stop-cocks $\mathrm{E}$ and $\mathrm{F}$ are opened and a rapid current of $\mathrm{CO}_{2}$ is turned on from G. The stop-cocks are then shut and the mercury bath $\mathrm{H}$ is raised into position. When absorption of $\mathrm{CO}_{2}$ is complete, a current of nitrogen is passed through the apparatus in the same way, but after bringing the mercury bath into position an initial negative pressure is created by suction before shutting the stop-cocks. A modified form of the apparatus, in which the rubber connexions are avoided, is also shown in Fig. 2, b. 
Influence of Carbon Dioxide. IV.

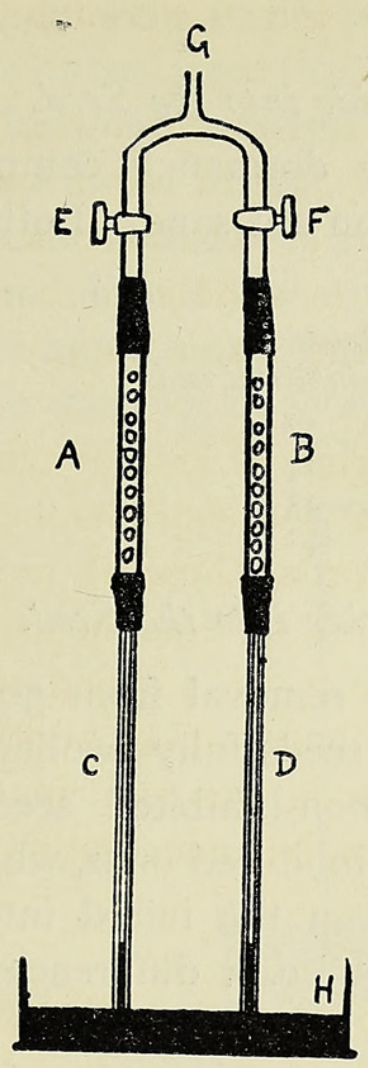

$a$.

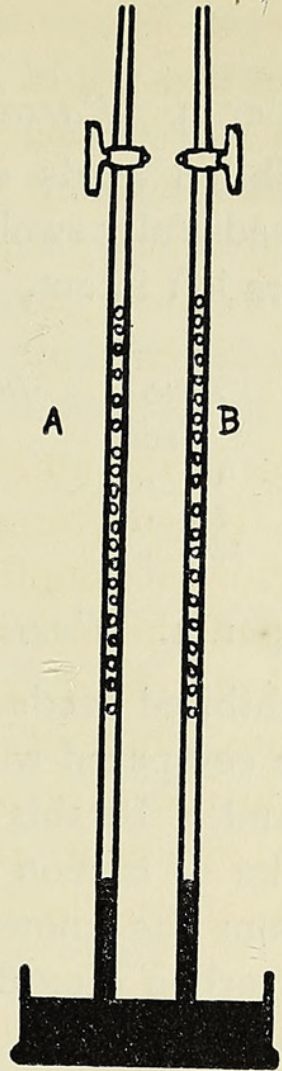

$b$.

TEXT-FIG. 2.

TABLE IX.

Exper. I. Passage of Carbon Dioxide into the Seed.

Ten inhibited seeds showing secondary dormancy compared with ten normal seeds fully swollen after one day on wet sand. The outer testas were removed in both cases.

$\begin{array}{ccc} & \text { Mercury rise in millimetres. } \\ \text { Time. } & \text { Inhibited seeds. } & \text { Non-inhibited seeds. } \\ 6 \text { min. } & 33 & 33 \\ \text { I I ", } & 38 \cdot 5 & 39 \\ \text { I6 ", } & 40 \cdot 5 & 41 \\ 60 ", & 52 & 54 \\ 3 \text { hrs. } & 59 & 6 \mathrm{I} \\ \text { I } 7 \frac{1}{2},, & 94 & 89\end{array}$

TABLE X.

Exper. 2. Passage of Carbon Dioxide out of the Seed.

The same seeds as in the above experiment, the carbon dioxide being displaced by a current of nitrogen after seventeen and a half hours.

Mercury fall in millimetres.

\begin{tabular}{|c|c|c|c|}
\hline \multicolumn{2}{|c|}{ Time. } & Inhibited seeds. & Non-inhibited seeds. \\
\hline & ain. & $8 \cdot 5$ & $8 \cdot 5$ \\
\hline 10 & , & $12^{\circ} 5$ & I 3.5 \\
\hline 16 & ," & $14^{\circ} 5$ & $16 \cdot 5$ \\
\hline 30 & " & 16 & 2 I \\
\hline 50 & " & $I_{7}$ & 24 \\
\hline 80 & " & 20 & 32 \\
\hline
\end{tabular}




\section{TABLE XI.}

Exper. 3. Passage of Carbon Dioxide into the Seed.

Eight inhibited seeds showing secondary dormancy compared with eight normal seeds fully swollen after one day on wet sand. Both outer and inner testas were left intact.

\begin{tabular}{rcc} 
& \multicolumn{2}{c}{ Mercury rise in millimetres. } \\
Time. & Inhibited seeds. & Non-inhibited seeds. \\
5 min. & 12 & I 2 \\
$10 "$, & 27 & 27 \\
$35 \%$, & 43 & 43 \\
$150 "$ & $7 \mathrm{I}$ & $7 \mathrm{I}$
\end{tabular}

Exper. 4. Passage of Carbon Dioxide into the Seed.

Twenty inhibited seeds immediately after removal from 30 per cent. carbon dioxide compared with twenty normal seeds fully swollen after one day on wet sand. In this experiment the non-inhibited seeds allowed a quicker uptake of carbon dioxide than the inhibited ones, which was to be expected from the known difference between the initial internal concentrations of carbon dioxide within the seeds, i.e. a difference of 30 per cent. approximately.

\section{TABLE XII.}

\section{Exper. 5. Passage of Carbon Dioxide out of the Seed.}

Same seeds as in the above experiment, the carbon dioxide being displaced by a current of nitrogen after four hours. Weight of twenty seeds $=0.24$ gramme. Approximate volume $=0.2 .5$ c.c.

\begin{tabular}{lcc} 
& \multicolumn{2}{c}{ Escape of carbon dioxide. } \\
Time. & Inhibited seeds. & Non-inhibited seeds. \\
85 min. & 0.125 c.c. & 0.135 c.c. \\
16 hours & 0.175 c.c. & 0.195 c.c.
\end{tabular}

Exper. 6 and 7. Passage of Carbon Dioxide into and out of the Seed.

The same seeds as in the above experiment, carbon dioxide being again run into the apparatus. The subsequent rise in four and a half hours amounted to 0.140 c.c. in the case of the inhibited, and O.I60 c.c. in the case of the noninhibited seeds. The carbon dioxide was then again displaced by nitrogen, and the subsequent escape of $\mathrm{CO}_{2}$ from the seeds proceeded at an equal rate.

Series $B$.

In these experiments, free testas of equal size were obtained by cutting off a sector of the seed and carefully removing the embryo. The permeability to oxygen of testas from inhibited and non-inhibited seeds respectively was compared by direct experiment.

Text-fig. $3, a$, represents the apparatus employed. The testas, $\mathrm{P}$, to be compared were fitted over two narrow glass tubes, $\mathrm{A}$ and $\mathrm{B}$, of equal bore, 
to which they were securely fastened with silk thread (see Text-fig. $3, b$ ). These glass tubes were inserted through corks in the bottom of a wooden trough. The joint between the testa and the glass tubes was sealed by mercury held in the trough. The glass vessel $\mathrm{D}$, through which a current of carbon dioxide was slowly passed, was placed over the trough as shown in the diagram. For a few minutes a rapid current of oxygen was passed through the tubes $\mathrm{A}$ and $\mathrm{B}$ via the lateral connexions $\mathrm{E}$ and $\mathrm{F}$. At a given moment the stop-cocks $\mathrm{H}$ and $\mathrm{J}$ were turned off, leaving an atmosphere of

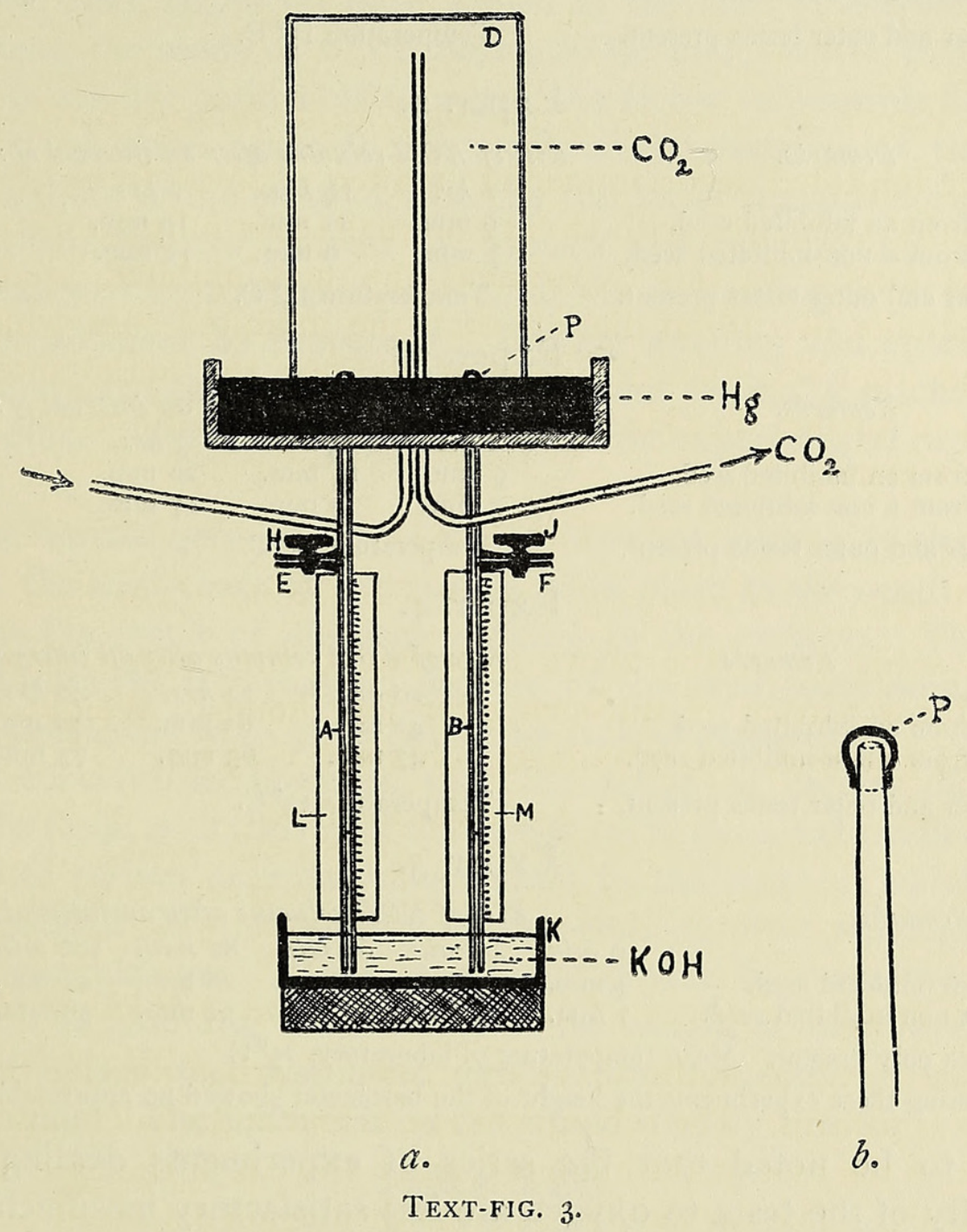

pure oxygen in the tubes A and B, the lower ends of which were allowed to dip into a concentrated solution of potassium hydrate contained in the vessel K. Now, since any carbon dioxide which penetrates the testa-membrane was immediately absorbed by the $\mathrm{KOH}$-solution, the actual rate of the passage of oxygen from the tubes $\mathrm{A}$ and $\mathrm{B}$ respectively through the seed-coat membranes was shown by the rise of the solution in these tubes, which was readily measured on the scales $\mathrm{L}$ and $\mathrm{M}$. In this way the permeability of any two testas was directly compared. 
The results thus obtained are tabulated below:

TABLE XIII.

Results of Experiments on the Permeability of the Seed-coats of White Mustard Seeds to Oxygen.

Exper. I.

Remarks.

Testa from an inhibited seed.

Testa from a non-inhibited seed.

Both inner and outer testas present.

\section{Remarks.}

Testa from an inhibited seed.

Testa from a non-inhibited seed.

Both inner and outer testas present.

Remarks.

Testa from an inhibited seed. Testa from a non-inhibited seed. Both inner and outer testas present.

\section{Remarks.}

Testa from an inhibited seed

Testa from a non-inhibited seed.

Both inner and onter testas present.

\section{Remarks.}

Testa from an inhibited seed.

Testa from a non-inhibited seed.
Rise of $K O H$ columns after an interval of:

$\begin{array}{llll}\frac{1}{2} h r . & \text { I } \frac{1}{2} h r s . & 3 \frac{1}{2} h r s . & 4 \frac{1}{2} h r s . \\ 6 \mathrm{~mm} . & \text { I } 2 \mathrm{~mm} . & 23 \mathrm{~mm} . & 25 \mathrm{~mm} . \\ 6 \mathrm{~mm} . & \mathbf{1} 2 \mathrm{~mm} . & 28 \mathrm{~mm} . & 31 \mathrm{~mm} .\end{array}$

Temperature $15^{\circ} \mathrm{C}$.

Exper. 2.

Rise of KOH columns after an interval of:

$\begin{array}{lll}\text { I } h r . \quad \text { I } \frac{1}{3} h r s . & 2 h r s . \\ 9 \mathrm{~mm} . & \text { II } \mathrm{mm} . & \text { I } 5 \mathrm{~mm} \text {. } \\ 7 \mathrm{~mm} \text {. } \quad 9 \mathrm{~mm} . & \text { I } 2 \mathrm{~mm} \text {. } \\ \text { Temperature }{ }^{\circ} 5^{\circ} \mathrm{C} . & \end{array}$

Exper. 3 .

Rise of $\mathrm{KOH}$ columns after an interval of:

$\begin{array}{lll}\mathrm{I} h r . & \text { I } \frac{1}{3} \mathrm{hrs} . & 3 \mathrm{hrs} . \\ 9 \mathrm{~mm} . & \text { II } \mathrm{mm} . & 20 \mathrm{~mm} \text {. } \\ 7 \mathrm{~mm} . & 9 \mathrm{~mm} . & \text { I } 7 \mathrm{~mm} \text {. } \\ \text { Temperature } \mathrm{I}_{5}{ }^{\circ} \mathrm{C} . & \end{array}$

Exper. 4.

Rise of $\mathrm{KOH}$ columns after an interval of:

$\begin{array}{lll}20 \mathrm{hrs} . & 24 \mathrm{hrs} . & 40 \mathrm{hrs} . \\ 42 \mathrm{~mm} . & 62 \mathrm{~mm} . & 7^{2} \mathrm{~mm} . \\ 43 \mathrm{~mm} . & 63 \mathrm{~mm} . & 73 \mathrm{~mm} .\end{array}$

Temperature $\mathrm{I} 5^{\circ} \mathrm{C}$.

Exper. 5.

Rise of $K O H$ columns after an interval of:

$20 \mathrm{~min}$. $40 \mathrm{~min}$. $60 \mathrm{~min}$. $80 \mathrm{~min}$. $100 \mathrm{~min}$. $120 \mathrm{~min}$. $4 \mathrm{~mm}$. $\quad$ I $3 \mathrm{~mm}$. $21 \mathrm{~mm}$. $28 \mathrm{~mm}$. $47 \mathrm{~mm}$. $5.3 \mathrm{~mm}$. $7 \mathrm{~mm}$. $\quad$ I $5 \mathrm{~mm}$. $24 \mathrm{~mm}$. $34 \mathrm{~mm}$. $56 \mathrm{~mm}$. $66 \mathrm{~mm}$.

Inner testa only present. Mean temperature of laboratory, ${ }_{1} 5^{\circ} \mathrm{C}$.

NB.-During these experiments the height of the barometer showed no appreciable change.

It is to be noted that the series of experiments dealing with the permeability of the testa to oxygen are less satisfactory inasmuch as single testas only are compared, and, moreover, a considerable amount of handling is unavoidable in setting up the experiments. In the series of experiments dealing with the permeability of the testa to carbon dioxide, the average effect of a number of seeds is measured and the seed-coats are intact.

The outstanding result of the above experiments is that the testa of White Mustard seeds, both in the inhibited and non-inhibited condition, is very permeable to oxygen and carbon dioxide. It cannot be said, however, that the experiments show that the testa of the inhibited seed is less permeable to either oxygen or carbon dioxide than that of the normal seed. 
The conclusion indicated is that neither lack of oxygen nor accumulation of carbon dioxide in the embryo controls the phenomenon of secondary dormancy. This conclusion is confirmed by the results of experiments described in a following section, in which it was found that germination of inhibited Brassica alba seeds could not be forced either by increasing the oxygen pressure or by lowering the internal carbon dioxide concentration in the seeds by exposure to a vacuum (see Table XXII).

\section{Changes in the Mechanical Resistance of the Seed-coats.}

Crocker and Davis (5) have shown in the case of Alisma Plantago, a water-plant, the seeds of which normally lie under water, that while the seed-coat is readily permeable to water, the factor responsible for the nongermination of these seeds is the mechanical resistance of the testa to physical swelling of the embryo, whereby the latter remains dormant owing to an insufficient water content for growth and germination. When the testa is weakened by treatment with acids the expanding force of the seedcontents is sufficient to rupture it. Further swelling and uptake of water by the embryo can then take place, and a point is finally reached at which growth begins. The same result is obtained by experimental rupture of the seed-coat.

In the normal germination of White Mustard seeds it is clear that the rupture of the seed-coats by the radicle takes place as the result of growth, ${ }^{1}$ and not as the result of physical swelling of the embryo. This may be concluded from the fact that no rupture of the seed-coats occurs in seeds which are prevented from germinating by lack of oxygen.

It is conceivable, however, that the action of carbon dioxide may toughen the testa, with the result that seeds set to germinate under inhibiting conditions of carbon dioxide do not swell to the point at which sufficient water is present for the growth of the embryo after removal from the inhibiting gas mixture. Direct experiment proves, however, that this is not the case. The following table compares the weight of fully swollen normal seeds, just before and just after germination respectively, with that of inhibited seeds. The latter are on the whole slightly heavier.

TABLE XIV.

Comparison between the Weight of Inhibited Seeds from Damp Sand and fully swollen (20 per cent. actually sprouting) Non-inhibited Seeds.

$$
\begin{aligned}
& \begin{array}{l}
\text { Weight of } 200 \\
\text { inhibited seeds. }
\end{array} \\
& \text { 2.4 } 1 \mathrm{grm} \text {. } \\
& 2 \cdot 51 \mathrm{grm} \text {. } \\
& { }^{2} 40 \mathrm{grm} \text {. } \\
& \text { Weight of } 200 \text { fully swollen non- } \\
& \text { inhibited seeds (soaked } \\
& \text { for 20-25 hours). } \\
& 2 \cdot 4 \mathrm{I} \mathrm{grm} \text {. } \\
& 2 \cdot 4 \mathrm{I} \mathrm{grm} \\
& 2 \cdot 24 \mathrm{grm} \text {. } \\
& \text { Average }=2 \cdot 35 \mathrm{grm} \text {. } \\
& \text { 2. Io grm. All germinated. }
\end{aligned}
$$

1 Histological examination of seeds during the period immediately preceding germination showed that the root forces its way through the seed-coats by growth pressure. No enzyme action was indicated. 
While it is thus clear that no change under the influence of carbon dioxide has occurred in the mechanical resistance of the testa sufficient to prevent the embryo from swelling to its normal size, and while we must conclude that sufficient water is present for the growth of the radicle to proceed, a further possibility remains. An increase in the breaking strain of the testa during the primary period of inhibition by carbon dioxide, although insufficient to produce any measurable effect on the physical swelling of the embryo, may yet prevent the growth of the radicle and so account for the non-germination of the seed.

Müller (6) draws a conclusion for certain seeds that the breaking strain of the testa is nominally only slightly less than the expansive force of the embryo, both lying in the region of three and a half atmospheres. The conclusions of Crocker (3) with regard to Amaranthus retroflexus may also
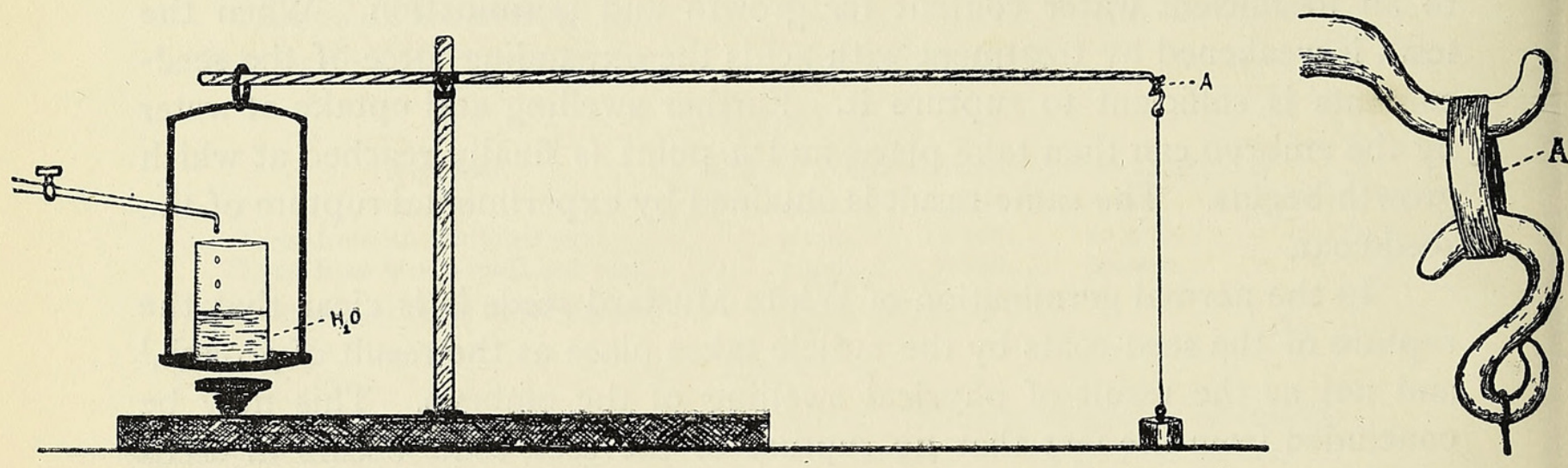

TEXT-FIg. 4.

be cited in this connexion. The seeds of this plant will not germinate immediately after gathering, but they will do so after a month or more of dry storage. The reason for this is that the colloids of the seed-coats by a slow process of hysteresis in the dry condition take on new characters which give them a much lower elasticity and breaking strain. When the seeds are soaked after this change has occurred, they are able to germinate by rupture of the seed-coats. If, however, germination is now prevented by keeping the wet seeds at subminimal temperatures, the colloids of the seedcoats in their saturated condition recover their former strength by a reverse process of hysteresis. The embryo is then no longer able to rupture the seed-coat when the temperature is raised, and a prolonged period of secondary dormancy ensues.

In view of these results of Crocker and of Müller, the following direct experiments were carried out to compare the breaking strain of the seedcoats of Brassica alba in the case of normally germinating seeds and in the case of seeds showing secondary dormancy after $\mathrm{CO}_{2}$-treatment.

The apparatus used is represented in Text-fig. 4. 
Seed-coat rings (A) were obtained from thick median sections of seeds. These seed-coat rings varied in breadth from $2 \mu$ to $20 \mu$, a micrometer reading being taken in each case at the point of rupture. In each experiment a number of rings from different seeds were taken and the average weight supported (in grammes per I $\mu$ of breadth) was calculated. This is possible since the relationship between the breadth of the ring and its breaking strain was found to be approximately linear over the range used. The sensitiveness of the apparatus was increased by making the arms of the balance of unequal length.

TABLE XV.

Mechanical Resistance of the Testa-breaking Strain of Seed-coat Rings.

Non-inhibited Seeds.

Time in germinator.

$3 \frac{1}{2} \mathrm{hrs}$.
$6 \mathrm{hrs}$.

Io hrs. (testas only soaked)

Io hrs. (whole seeds soaked)

2 days ( 3 actually germinating)

3 days (kept under water)

Number of
seed-coats
tested.
I I
9
8
9
7
7

Average weight supported

by testa-ring per $\mu$

of breadth.

$3 \cdot 3$ grm.

2.3 grm.

1.9 grm.

$\mathrm{I} \cdot 4 \mathrm{grm}$.

I $\circ$ grm.

I.2 $\mathrm{grm}$.
Ist Sample.

Time after renoval from the inhibitory gas-mixture.

2nd Sample.

$$
\begin{aligned}
& 5 \text { days * } \\
& \text { I } 5 \text { days } \\
& 23 \text { days }
\end{aligned}
$$

Immediately 5 days

\section{Inhibited Seeds.}

Number of seed- Average weight supported by testa-
coüts tested.

$2.9 \mathrm{grm}$.
I.3 grm.
$0.9 \mathrm{grm}$.
I.2 $\mathrm{grm}$.
$0.9 \mathrm{grm}$.

$2.9 \mathrm{grm}$.

13

I 4

I I

10

10
I 2 grm.
$0.9 \mathrm{grm}$.

* No germinations occurred in this sample of inhibited seeds up to a period of two months.

The results of these direct measurements indicate that the condition of secondary dormancy in White Mustard seeds cannot be attributed to an increase in the breaking strain of the seed-coats by which the growth of the radicle is prevented. When the lowest values obtained for seeds undoubtedly in a condition of secondary dormancy are compared with the values obtained for untreated seeds on the point of germination, the figures are from $\mathrm{I} \cdot 3$ to 0.9 as against from $\mathrm{I} \cdot 4$ to $1 \cdot 0$. The results further indicate that the breaking strain of the seed-coat is subject to considerable variation. In the case of freshly soaked untreated seed it is clear that the breaking strain of the seedcoat continues to fall for some time after they have become water-saturated and pliant. In the case of inhibited seeds showing secondary dormancy, continued exposure on damp sand results in a gradual decrease in the 
breaking strain of the testa, due in all probability to secondary causes such as bacteria and acid accumulation.

\section{Changes in the Embryo.}

The experiments already described having thus given no definite indication of a change occurring in the seed-coats such as would be sufficient to account for secondary dormancy, it became necessary to consider the possibility of some change occurring in the embryo.

To this end a comparison was made between the germination and growth of bare embryos removed from seeds showing secondary dormancy and bare embryos from normal untreated seeds respectively.

In these experiments the seed-coats were removed with special care and the bare embryos were placed on damp filter-paper dipping into water in a closed vessel. The filter-paper was in some cases hung horizontally and in other cases supported in a slanting position on glass, the embryo being placed about $\mathrm{I} \mathrm{cm}$. above the water-level. When the tap roots develop they grow down into the water. In the case of the control with

\section{TABLE XVI.}

Persistence of Secondary Dormancy after Removal of the Seed-coats.

\begin{tabular}{|c|c|c|c|c|c|c|c|c|}
\hline \multirow{2}{*}{$\begin{array}{l}\text { Experi- } \\
\text { ment. }\end{array}$} & \multirow{2}{*}{$\begin{array}{l}\text { Number } \\
\text { of seeds } \\
\text { used. }\end{array}$} & \multirow{2}{*}{\multicolumn{2}{|c|}{ Remarks. }} & \multicolumn{4}{|c|}{$\begin{array}{l}\text { Percentage of seeds } \\
\text { ungerminated after- }\end{array}$} & \multirow{2}{*}{$\begin{array}{l}\text { Previous history of the } \\
\text { seeds used in these } \\
\text { experiments. }\end{array}$} \\
\hline & & & & I & $\begin{array}{l}4 \\
\text { days. }\end{array}$ & $\begin{array}{l}8 \\
\text { days. }\end{array}$ & $\begin{array}{c}\text { I2 } \\
\text { days. }\end{array}$ & \\
\hline No. I & 10 & $\begin{array}{l}\text { Control experimen } \\
\text { fully swollen unir } \\
\text { seeds. }\end{array}$ & $\begin{array}{l}\text { at with } \\
\text { nhibited }\end{array}$ & ० & 0 & o & o & \\
\hline No. 2 * & 8 & Kept in the dark at & $20^{\circ} \mathrm{C}$ & 100 & 50 & 0 & ० & $\begin{array}{l}2 \text { I days in inhibiting } \\
\text { gas-mixture. Set } 20 \\
\text { days after removal. }\end{array}$ \\
\hline No. 3 & I0 & " & $12 \cdot 5^{\circ} \mathrm{C}$ & 100 & IO & $\circ$ & ○ & $\begin{array}{l}\text { I9 days in inhibiting } \\
\text { gas - mixture. Set } 3 \\
\text { days after removal. }\end{array}$ \\
\hline No. 4 & IO & $"$ & " & 100 & 40 & IO & IO & Ditto. \\
\hline No. $5 \dagger$ & I 2 & $\because$ & $"$ & 100 & $5^{\circ}$ & 43 & 8 & $\begin{array}{l}\text { I7 days in inhibiting } \\
\text { gas-mixture. Set I } 4 \\
\text { days after removal. }\end{array}$ \\
\hline No. 6 & 20 & Kept in the light at & $20^{\circ} \mathrm{C}$ & 40 & 5 & $\circ$ & $\circ$ & $\begin{array}{l}24 \text { days in inhibiting } \\
\text { gas-mixture. Set I } 5 \\
\text { days after removal. }\end{array}$ \\
\hline No. 7 & 7 & Kept in the dark at & $12.5^{\circ} \mathrm{C}$ & 85 & I 5 & 0 & ○ & $\begin{array}{l}\text { I9 days in inhibiting } \\
\text { gas - mixture. Set } 3 \\
\text { days after removal. }\end{array}$ \\
\hline No. 8 & I0 & $"$ & " & 50 & ० & ○ & ० & Ditto. \\
\hline No. 9 & 20 & ", & $16^{\circ} \mathrm{C}$. & 100 & 50 & 20 & 20 & $\begin{array}{l}45 \text { days in } 28 \% \mathrm{CO}_{2} \\
\text { 10\% oxygen. } \\
\text { immediately after re- } \\
\text { moval. }\end{array}$ \\
\hline
\end{tabular}

* Cf. Plate XXIII, Fig. I, A and B.

† Cf. Plate XXIII, Fig. 2, A and B. 
normal untreated seeds, the seed-coats were removed after ten hours' soaking; germination and growth of the bare embryos proceeded immediately. Eight experiments were conducted with embryos from inhibited seeds, "the results of which may be summed up as follows (see Table XVI). In all cases a certain number of seeds, usually about 50 per cent., started to germinate after removal of the testa with a short lag amounting to about twenty hours. Where germination did not ensue in this way almost immediately, a definite continuation of the dormant condition became apparent. The period of this dormancy varied in these experiments from three to thirteen days. The cotyledons and radicle enlarged to a considerable extent by inhibition of water, and, where exposed to light, the former assumed their green colour. The whole embryo, however, had the appearance of a fully mature organ without the capacity for growth. Neither the hypocotyl nor the radicle showed the least sign of elongation by growth in the normal fashion. The photographs (Plate XXIII, Figs. I and 2) show the marked contrast between the embryos in this dormant condition several days after the removal of the testa and those seedlings in which growth had started almost immediately.

With regard to the appearance and rate of growth after germination had once commenced, no marked difference was observed between the embryos of control untreated seeds and those of seeds showing secondary dormancy.

These experiments afford the second piece of positive evidence in this research with regard to the causes underlying the phenomenon of secondary dormancy in White Mustard. In the first section of this paper it was shown that changes in the embryo resulting in injury prohibited the occurrence of secondary dormancy. It now appears that in the case of seeds in which secondary dormancy has been successfully induced, changes occur which render them less sensitive to normal growth conditions than the tissues of a newly-swollen untreated seed.

The interpretation of secondary dormancy must now be, not that any change has occurred in the seed-coat, but that the power of the embryo to rupture the testa and germinate has been reduced. As has already been pointed out, the rupture of the seed-coat in Brassica alba results from a process of growth. In other words, the power of the embryo to respond to growth conditions and to germinate under the limitation of the seedcoats decreases during the primary period of inhibition in the presence of carbon dioxide.

On the other hand, the broad fact that by the removal of the seedcoats the germination of seeds showing secondary dormancy can be induced must not be lost sight of. In the first place, it is impossible to remove the seed-coats with a fine sharp needle, the method employed in our experiments, without almost certainly causing some injury to the superficial cells of the embryo, or, at any rate, giving the whole tissue considerable $\mathrm{K} \mathrm{k}$ 
mechanical shock by torsion and pressure. This in itself may be sufficient to upset the dormant condition of the embryo, and may account for the almost immediate germination of the majority of the embryos employed in the above experiments and for the fact that the dormant condition of the embryo itself had not been previously discovered in the many experiments in which the testa had been completely removed in order to induce germination of dormant seeds.

In the second place, by the removal of the testa, both the entrance of oxygen and the escape of carbon dioxide are facilitated. Thirdly, a further physical uptake of water occurs after the removal of the testa. In the following table the further swelling which occurs in the radicle of seeds showing secondary dormancy, after removal of the testa, is indicated. It is possible that the tissues are less stable in the fully swollen condition.

\section{TABLE XVII.}

Further Uptake of Water by Excised Radicles of Seeds showing Secondary Dormancy after Removal of the Testa.

Time.
5 min.
I I ",
20
32
$60 "$,
$69, "$
28 hrs.

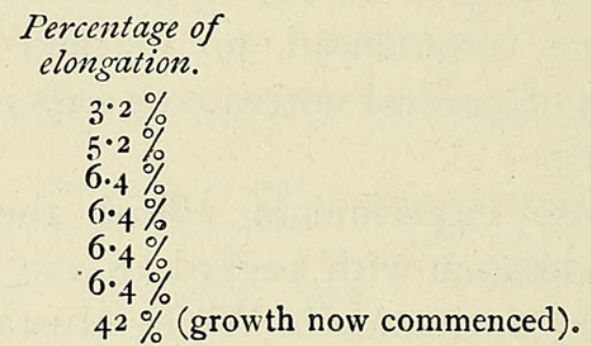

Before the removal of the testa these seeds were soaked several hours under water.

Mean temperature of laboratory, $15^{\circ} \mathrm{C}$.

\section{\$4. Methods of Forcing Germination of Brassica alba Seeds SHOWing SECONDARY DORMancy.}

The present section proceeds to experiments dealing with the effect of various treatments in forcing the germination of Brassica alba seeds showing sêcondary dormancy.

\section{Removal or Partial Removal of the Testa.}

It has already been shown that complete removal of the testa induces germination; this fact has been discussed at length in the preceding section. It was found, however, in addition, that a considerable percentage of seeds germinated immediately after the removal of the outer testa only; ${ }^{1}$ a similar result was obtained by the removal of a small sector of the testa over any part of the embryo. The following table summarizes the results - of the experiments conducted : 


\section{TABLE XVIIL.}

Effect of Partial or Complete Removal of the Testa in forcing Germination of White Mustard Seeds showing Secondary Dormancy.

Treatment of inhibited seed.

Not removed to fresh sand. Removed to fresh sand.

Outer testa removed with a needle.

Outer testa rubbed off with a towel.

Both testas removed.

Portion of the testa over the hilum removed.

Portion of the testa opposite the hilum removed.

Control: new uninhibited seeds.
Percentage of germinated seeds after-

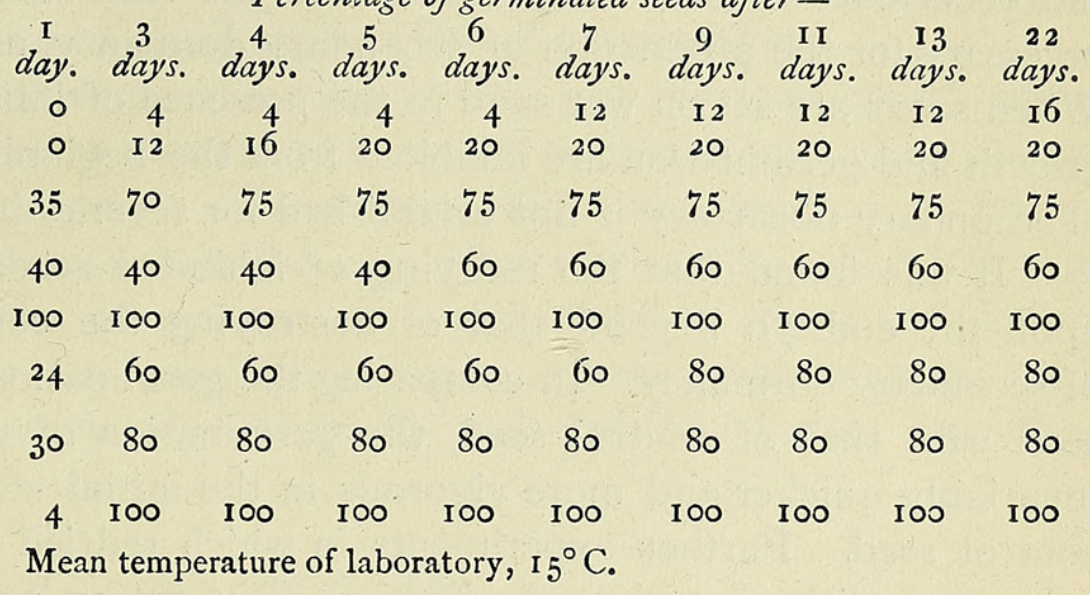

The seeds which failed to germinate immediately as the result of either of these treatments remained dormant for an indefinite period. These facts, without being conclusive, indicate that the germinations induced result from the mechanical stimulus on the embryo of the treatment rather than from any change or weakening in the testa. The experiments in which a sector of the testa was removed would seem to rule out the factor of mechanical restraint as being operative for those seeds which subsequently continued dormant. This factor must have been practically reduced to a minimum.

\section{Redrying.}

It has been shown in a previous paper $(1$, p. 416$)$ that by redrying seeds showing secondary dormancy, the capacity for immediate germination is restored. Further investigation during the course of this research showed, however, that a time factor is also involved. Thus, a sample of twenty-five seeds redried for three days in air at laboratory temperature gave only 25 per cent. germination during ten days when reset to germinate on wet sand. On the other hand, inhibited seeds redried for a month in air at the laboratory temperature gave 100 per cent. germination in two days.

In interpreting these results in view of the fact that no marked change in the mechanical resistance of the testa occurs (see Table XV), and also in view of the fact, which has already been demonstrated, that the seedcoats are extremely permeable both to oxygen and to carbon dioxide, we conclude that the redrying of the embryo destroys the dormant condition $\mathrm{K} \mathrm{k} 2$ 
which was found to be established in the embryo during secondary dormancy. The occurrence of a time factor is interesting since it indicates that the changes involved, by which dormancy is removed, are secondary to the changes involved in drying. In this connexion it should be remembered that an interval of time, pointing in all probability also to the occurrence of secondary changes in the saturated embryo, was found necessary for the production of secondary dormancy, as shown in section 1. When seeds are set on wet sand in the presence of inhibiting gas mixtures, growth and germination are inhibited from the beginning, but the condition of secondary dormancy is not established for several days.

It was found that the redrying of inhibited seeds has a further effect upon the embryo beyond that of destroying the condition characteristic of secondary dormancy. In comparing the germination of redried inhibited seed with that of control seed, the germination of the redried seed was invariably quicker and more vigorous in the initial stages than that of the control seed. Further experiments in which redried inhibited seeds were compared with control seeds, redried after fifteen hours' soaking, showed that this acceleration is a result of the redrying of the seeds and is not

\section{TABLE XIX.}

The Accelerated Germination of Redried White Mustard Seeds.

\begin{tabular}{lccc}
\multicolumn{1}{c}{ Experiment. } & \multicolumn{3}{c}{ Germinations after- } \\
& 26 hours. & $4^{\text {S hours. }}$ & 70 hours. \\
Control ; fresh seed. & 0 & 8 & 10 \\
Redried inhibited seed. & 9 & 10 & 10 \\
Redried non-inhibited seed. & 9 & 10 & 10 \\
Redried inhibited seed. & 9 & 10 & 10
\end{tabular}

Io seeds used in each experiment. Temperature $=\mathbf{I} 8^{\circ} \mathrm{C}$. In light.

connected with previous inhibition or with secondary dormancy. The redrying of soaked seeds appears to act as a definite stimulus. In the case of control seeds redried after soaking, a varying proportion showed at the same time visible injury to the radicle. A second swelling and redrying increases this proportion. Further, if germination has occurred, redrying invariably kills the radicle. The case of redried inhibited seeds is in contrast to this. It is to be emphasized that when redried inhibited seeds are set to germinate all the radicles develop in a perfectly healthy and normal manner. Inhibition and secondary dormancy can be induced a second time. Redrying will again destroy the dormant condition. The radicles, however, still all remain healthy and normal. From these facts it may be concluded : (i) that redrying of fully swollen normal seeds at an early stage of development previous to germination results in an accelerated germination when the seeds are subsequently resown; (ii) that redrying of 
fully swollen seeds at a later stage of development after the process of cell division has advanced results in injury; (iii) that both injury and acceleration of germination are due to changes of the same nature resulting from redrying; and (iv) that in the case of secondarily dormant seeds the effect of redrying, while not causing injury owing to the absence of cell-division, is not only sufficient to break up the dormant condition of the embryo, but also to cause acceleration of germination.

A series of experiments was conducted to test the reaction of redried inhibited seeds to carbon dioxide with regard to inhibition. It was found that a smaller concentration of carbon dioxide was required to initiate inhibition than that required in the case of normal seeds. The following table gives the results of one set of experiments in which the control non-inhibited seeds soaked and redried are compared with inhibited seeds which have been previously inhibited and redried during secondary dormancy:

\section{TABLE XX.}

The Increased Sensitiveness of Redried Inhibited White Mustard Seeds to the retarding and inhibiting Action of Carbon Dioxide. $\begin{array}{cl}\text { Percentage of } \mathrm{CO}_{2} & \text { Number of germinations after- } \\ (20 \% \text { oxygen in each case). } & 46 \text { hours. } 97 \text { hours. } 120 \text { hours. }\end{array}$

\begin{tabular}{|c|c|c|c|}
\hline 0 A & 19 & 20 & 20 \\
\hline $0 \%$; & 20 & 20 & 20 \\
\hline$\%\{\mathrm{~A}$ & F9 & 20 & 20 \\
\hline$\%\{\mathrm{~B}$ & 16 & 17 & I9 \\
\hline $10 \%$ A & 18 & I9 & 19 \\
\hline $10 \%$ B & 5 & I 2 & I 2 \\
\hline $16 \% \mathrm{~A}$ & I 7 & 18 & 18 \\
\hline & 0 & 3 & 3 \\
\hline
\end{tabular}

20 seeds used in each experiment.

Temperature $17-19^{\circ} \mathrm{C}$.

In light.

In each case seeds A and B were set side by side in the same flask.
Number of seeds still ungerminated after $a$ further i 3 days in air.

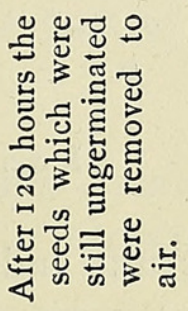

4

9

$A=$ control non-in hibited seeds soaked and redried.

$\mathrm{B}=$ inhibited seeds showing secondary dormancy redried.

Similar results were obtained when fresh control seed was used. The increased sensitiveness to the influence of carbon dioxide is clearly due to the fact of previous inhibition and not to the fact that the seeds have been soaked and redried. As will be seen also from the above table, secondary dormancy is again produced when redried inhibited seeds are submitted to the influence of carbon dioxide under germinating conditions a second time.

Temperature. The following table gives the results of experiments in which the endeavour was made to bring about germination of seeds showing secondary dormancy by exposure to high or low temperatures : 


\section{TABLE XXI.}

\section{The Effect of High and Low Temperatures in causing Germination of Brassica alba Seeds showing Secondary Dormancy.}

Treatment of inhibited
seeds.

$50^{\circ} \mathrm{C}$. for 3 hours, then returned to laboratory temperature.

$50^{\circ} \mathrm{C}$. for $\frac{1}{2}$ hour, then returned to laboratory temperature.

$25^{\circ} \mathrm{C}$. continuously.

Control: inhibited seeds kept at laboratory temperature throughout.

$\mathrm{I}-3^{\circ} \mathrm{C}$. for 3 days, then returned to laboratory temperature.

$0^{\circ} \mathrm{C}$. for 5 hours, then returned to laboratory temperature.

$-4^{\circ} \mathrm{C}$. for 3 hours, then returned to laboratory temperature.

$-7^{\circ} \mathrm{C}$. for 5 hours, then returned to laboratory temperature.

Control: inhibited seeds removed to fresh sand at laboratory temperature.

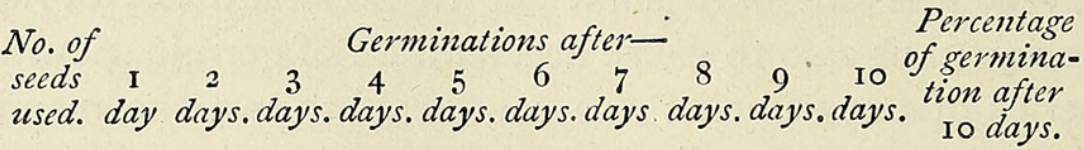

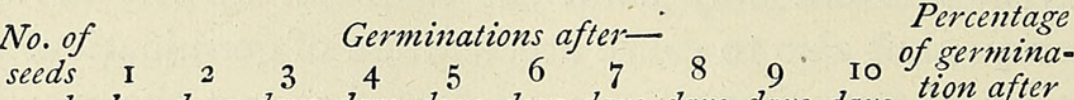
used. day days. days. days. days. days. days days. days. days. $\begin{gathered}\text { tion after } \\ \text { Io days. }\end{gathered}$

Remarks.

20

20

$20 \quad 12 \quad 13$

20

20

200

20

200

50

50

25

50

\author{
a $\quad 0 \% \quad$ All dead.
}

All healthy seed. lings.
All healthy seedlings.

The ungerminated seeds were killed.

The above results indicate that germination can be induced by short exposure to the extremes of high or low temperature which just fall short of injury; exposure to intermediate temperatures, either for a short period or continuously, has no effect. Thus, exposure to $50^{\circ} \mathrm{C}$. for half an hour was followed by 90 per cent. germinations, but exposure for three hours to the same temperature was fatal, while continuous exposure to $25^{\circ} \mathrm{C}$. had no effect. In a similar way, exposure to $-7^{\circ} \mathrm{C}$. for five hours resulted in 40 per cent. healthy germinations, but the remaining 60 per cent. were killed. ${ }^{1}$ Exposure to $0^{\circ} \mathrm{C}$. for three days, on the other hand, had no effect in causing germination of inhibited seeds.

1 In this connexion it is interesting to note that fully swollen normal seeds of Brassica alba submitted to the same temperature (i. e. $-7^{\circ}$ C.) in parallel with the above experiment showed marked injury without exception. The sharp contrast in this case between the ro seeds which germinated in the normal manner and the ${ }_{5} 5$ which did not germinate, and which when tested by removal of the testa proved to be killed, is probably to be accounted for by the fact that the injurious effect of low temperatures is due to the formation of ice-crystals which would occur at a critical point depending upon the concentration of the cell-sap. 


\section{Oxygen.}

Experiments conducted by Crocker (7) [Xanthium], Shull (8) [Xanthium], and by Rose (9) [Datura Wrightii and Martynia sp.] have led these authors to conclude that with these seeds the factor limiting germination is the low permeability of the testa to oxygen. The results of Atwood (10) indicate a similar conclusion with regard to Avena fatua. As has been said above, a possible cause of the non-germination of White Mustard seeds after treatment with carbon dioxide may be either lack of oxygen or excess of carbon dioxide. It has been shown that the seed-coats do not appear to change with regard to their permeability to gases as the result of the treatment which produces secondary dormancy. But owing to the alteration in the condition of the embryo, already demonstrated, it is quite possible that the normal interference of the testa in gaseous interchange may act as a definite factor in the maintenance of secondary dormancy. It has been seen that the seeds showing secondary dormancy which have been redried are more sensitive to carbon dioxide. This increased sensitiveness in all probability exists previous to redrying.

The following experiments were conducted : Inhibited White Mustard seeds were placed in concentrations of oxygen up to Ioo per cent. at one atmosphere pressure. No increase of germinations over the control in air resulted, and we may therefore conclude that the failure to germinate cannot be attributed to a need of oxygen on the part of the embryo.

\section{TABLE XXII.}

Negative Result of Treatment of White Mustard Seeds showing Secondary Dormancy with Increased Concentrations of Oxygen and of Treatment to Exposure to a Vacuum.

\begin{tabular}{|c|c|c|c|c|c|c|c|c|c|c|}
\hline \multirow{2}{*}{$\begin{array}{l}\text { Treatment of } \\
\text { inhibited seeds. }\end{array}$} & \multicolumn{10}{|c|}{ Number of germinations on removal to air after- } \\
\hline & $\stackrel{\mathbf{I}}{d a y}$ & 2 & 3 & 4 & 5 & 6 & 7 & 8 & & IO \\
\hline $\begin{array}{l}\text { Control inhibited } \\
\text { seeds in open flask. }\end{array}$ & 0 & 3 & 4 & 5 & 5 & 5 & 5 & 5 & 5 & 5 \\
\hline & 0 & 0 & 0 & 0 & 0 & 0 & 0 & 0 & 0 & 0 \\
\hline $\begin{array}{l}100 \% \text { oxygen. } \\
\text { Exhausted } \frac{1}{2} \text { hour }\end{array}$ & ○ & 0 & 0 & 0 & I & $\mathbf{I}$ & I & I & I & I \\
\hline $\begin{array}{l}75 \mathrm{~mm} \text {. } \mathrm{HgO}_{2} \\
\text { pressure admitted } \\
\text { for two days. }\end{array}$ & 0 & 0 & 0 & 0 & 0 & 0 & 0 & 2 & 2 & 2 \\
\hline
\end{tabular}

25 seeds used in each experiment.

Mean temperature of laboratory, ${ }^{\circ} 5^{\circ} \mathrm{C}$.

To test, on the other hand, the possibility of continued inhibition being due to an inhibiting concentration of carbon dioxide in the embryo owing to an increased sensitiveness to this gas on the part of the embryo, inhibited seeds were submitted to a vacuum for a short period and then 
placed in an atmosphere of pure oxygen at $75 \mathrm{~mm}$. Hg pressure, i. e. a tension of oxygen equal to half that in air. This treatment had no effect in stimulating the germination of seeds showing secondary dormancy and indicates that an inhibiting concentration of carbon dioxide in the tissues is not the cause of secondary dormancy.

\section{Acids.}

Crocker and Davis (5), working with dormant seeds of Alisma Plantago, concluded that the effect of acids in producing germination was due to their weakening action upon the seed-coat. Eckerson (11), however, showed that in the case of Crataegus mollis, Pyrus malus, \&c., dilute acids also affected the internal factors controlling the length of the so-called after-ripening period, while Lehmann (12) found that the action of acids and of certain hydrolysing enzymes can replace the action of light in producing the germination of dormant light-sensitive seeds, and took the view that hydrolysis is the important factor, but in this connexion it should be pointed out that he does not clearly distinguish between the seed-coat and the embryo itself.

Experiments were conducted to test the effect of dilute acids upon White Mustard seeds showing secondary dormancy. Hydrochloric and propionic acids were used. It was found in result (Table XXIII) that the effect of acids in increasing concentration was as follows: With $\mathrm{HCl}$, for example, the lowest concentration used, namely $\frac{N}{\mathrm{I}, 000}$, had little effect, whilst higher concentrations $\left(\frac{N}{100}\right)$ induced germination, but subsequently killed the primary root. Similarly, $\frac{N}{100}$ propionic acid caused 80 per cent. germination in two days, but subsequently killed all the seeds.

\section{TABLE XXIII.}

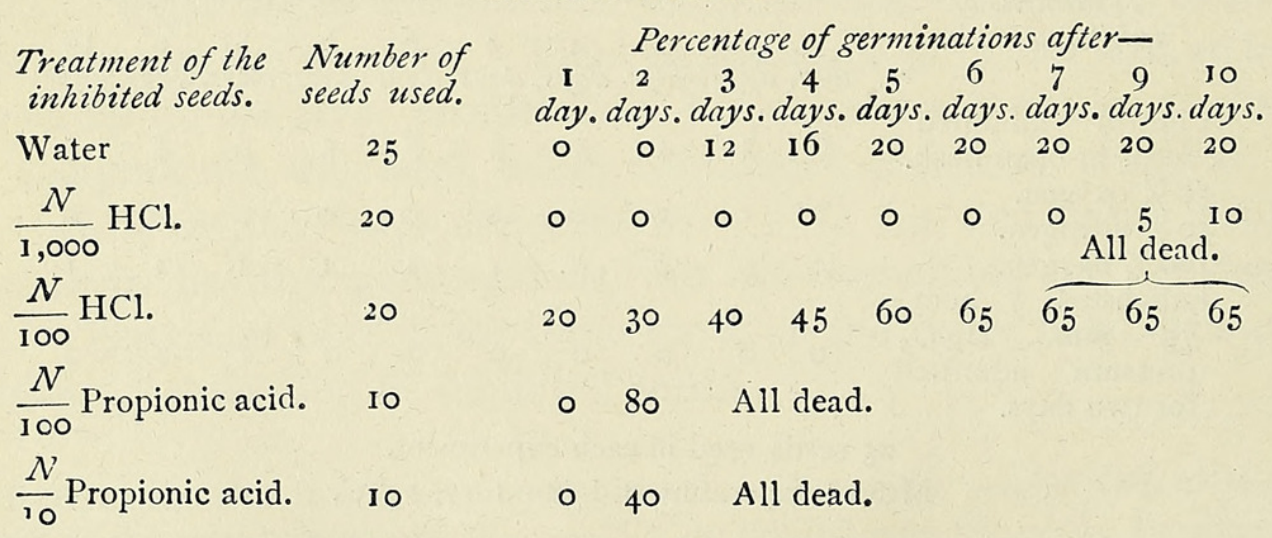

Mean temperature of laboratory, $16^{\circ} \mathrm{C}$.

The results of these experiments with acids lead us to a conclusion similar in nature to that already stated with regard to the action of temperature, namely, that germination of dormant White Mustard seeds 
can be induced by acid concentrations which are actually toxic to the growing radicle, or by concentrations which closely approximate to this. In other words, the conditions of acid concentration on the threshold of injury to the growing radicle will cause germination. ${ }^{1}$

In view of the results obtained with the above acids, and of the previous results in which it has been shown that following treatment with high concentrations of carbon dioxide secondary dormancy does not occur, experiments were conducted to test whether treatment with a high concentration of carbon dioxide would terminate the secondary dormancy of seeds inhibited by a lower concentration. Positive results were obtained. Treatment of seeds which had been inhibited by 25 per cent. carbon dioxide and 20 per cent. oxygen for twelve days, and which had lain dormant for two weeks subsequently in air, by an immersion for seven days in 100 per cent. carbon dioxide was followed by 95 per cent. germination in two days. The seeds not treated with 100 per cent. carbon dioxide remained dormant.

\section{§. Summary.}

The presence of carbon dioxide inhibits the germination of seeds, and the concentration of carbon dioxide necessary is correlated with temperature and with oxygen supply as previously described (2).

In the case of Brassica alba, the primary effect of carbon dioxide in causing inhibition of germination is followed by a secondary effect of prolonged dormancy after the carbon dioxide has been removed. This phenomenon has been termed secondary dormancy.

Changes in the seed-coat occurring during the period of primary inhibition have been suggested as the immediate cause underlying the phenomenon of secondary dormancy in White Mustard seeds, namely, $(a)$ a decreased permeability of the seed-coats to carbon dioxide or to oxygen occurring either as a result of a process of hysteresis in the colloids of the seed-coats (cf. Crocker, 3) or as a result of the specific action of carbon dioxide (Kidd, 1 ), or $(b)$ an increase in the mechanical resistance of the seedcoats. No evidence was found in support of either of these hypotheses.

It was found, on the other hand, that the embryos of secondarily

1 The interesting fact is to be recorded here that the ungerminated seed is far more resistant to acid injury than the growing radicle. Our experiments with carbon dioxide constantly demonstrated this fact; at ordinary temperatures $\left(20^{\circ} \mathrm{C}\right.$. circa), any germinations that occur in the presence of 20 per cent. carbon dioxide ( 20 per cent. oxygen present) show marked injury to the radicle. Further, embryos, removed from their seed-coats, which can sprout in the presence of this concentration of carbon dioxide, invariably show injury after ten days' immersion. Again, the radicles of seeds which are just sprouting when placed in 20 per cent. or in higher concentrations of carbon dioxide ( 20 per cent. oxygen present) always suffer injury. In contrast, seeds inhibited in 20 per cent. carbon dioxide (20 per cent. oxygen present), when finally induced to germinate, show no signs of injury to the radicle. Concentrations of carbon dioxide up to soo per cent., provided that the period of immersion does not exceed six days, and longer periods in the case of lower percentages, cause no injury to ungerminated seeds whether previousiy inhibited or not. 
dormant seeds have become more stable and less responsive to the conditions under which growth is usually initiated. The bare embryos of secondarily dormant seeds continue dormant under appropriate conditions after the removal of the seed-coats. This change in the embryo appears to be due to the action of carbon dioxide during the period of primary inhibition, as it cannot be induced by restraining germination by other means, e. g. by submitting the seeds to low temperatures.

The embryo enclosed within the seed-coats is not completely swelled, but the rupture of the seed-coats when germination takes place, both in the case of normal seeds and in the case of seeds showing secondary dormancy, is due to a process of growth.

The dormant condition of the growing tissues of the embryos of seeds showing secondary dormancy is broken up by treatments which are injurious, but not fatal. Treatments which actually kill the meristematic cells of the root-tip whilst still enclosed within the seed-coats cause the adjacent cells of the hypocotyl to start growing, and germination, in which the root-tip is absorbed, results.

As a corollary, if the conditions during the primary period of carbon dioxide inhibition are injurious, either owing to lack of oxygen or to excess of carbon dioxide, secondary dormancy does not ensue. In consequence, a high percentage of secondary dormancy can only be produced by a limited range of carbon dioxide and oxygen mixtures (i.e. 20 per cent. to 30 per cent. $\mathrm{CO}_{2}$ and not less than 15 per cent. $\mathrm{O}_{2}$ ).

Embryos in their completely swollen condition still showing secondary dormancy after the removal of their seed-coats are more sensitive to growth stimuli than those still enclosed in their seed-coats and consequently not completely swelled. While in the latter case germination can only be induced by conditions which just fall short of producing visible injurious effects, in the former case it is only possible to maintain the secondary dormancy by removing the testa with the greatest care in avoiding as far as possible pressure torsion or abrasion.

It will be seen that the main interest of this communication centres round the causes underlying the initiation of growth rather than in the condition of dormancy. In considering this question of growth in the case of Brassica alba seeds, our experiments show clearly that there is no question of limiting factors. We have been able to trace no limiting factor responsible for the non-germination of White Mustard seeds showing secondary dormancy. We find ourselves rather in the presence of facts which emphasize a conception of stimulus. It has been seen that widely different treatments, quite unclassifiable in any feature other than that they all result in injury and death if carried too far, excite germination and growth of dormant White Mustard seeds. It appears to us probable that some return will have to be made to this conception of stimulus in plant physiology 
generally, and that in any experimental analysis of the living plant, as a unit and in relation to its life-cycle, the idea of limiting factors, which has for so long dominated the minds of plant physiologists, will have to be modified.

\section{§6. ConClusions.}

Secondary dormancy in seeds of Brassica alba is not due either to increased mechanical restraint of the seed-coats or to decreased permeability of the seed-coats to gases. It is due to a stable condition of the embryo tissue, which becomes slowly established during the period of primary inhibition under the influence of carbon dioxide. This condition appears to be comparable to that of mature organs and of embryos maturing on the parent plant. The embryos of White Mustard in this stable condition (secondary dormancy) do not respond to the ordinary environmental factors under which germination and growth will proceed.

For the initiation of growth (by cell division) a change in the state of tissue equilibrium must occur, and this requires a definite stimulus. This change in the case of secondarily dormant White Mustard seeds is brought about by various treatments which cause injury and death when carried too far. The processes involved in the initiation of growth seem to be of the same kind as those which produce injury.

Imperial College of Science and Technology, LONDON,

May, I9I 7 .

\section{APPENDIX.}

Structure and Microchemistry of the Testa.

The complete testa of the young green seed of Brassica alba consists of the following layers of cells: ${ }^{1}$

The layers numbered $\mathrm{i}-\mathrm{iv}$ in Text-fig. $5, \mathrm{~A}$ and $\mathrm{B}$, constitute the socalled outer testa or seed-coat, which, in the ripe seed, can readily be removed from the inner testa or seed-coat.

i. An epidermis of large cells, which, in the mature seed, undergo complete mucilaginous degeneration.

ii. A layer ( $\mathrm{I}-3$ cells in thickness) of large thin-walled cells which also undergo complete mucilaginous degeneration when the seed ripens.

iii. A layer of large thin-walled cells which, in the ripe seed, undergo partial mucilaginous degeneration. The cell walls of layers $\mathrm{i}$, ii, and iii give the staining reactions characteristic of pectin.

1 For further details regarding the structure of the seed-coat in the genus Brassica the reader is referred to Holfert, J. : Die Nährschicht der Samenschalen, in Flora, Bd. 1xxiii, I890; and to Schroeder, J.: Untersuchung der Samen der Brassica-Arten und Varietäten, in Landw. Versuchs. Stationen, Bd. xiv, 1871 . 
iv. A layer of narrow radially elongated cells with characteristic highly refractive thickenings of the inner and radial walls (Textfig. 5, A and B). These cells have coarsely granular contents and distinct nuclei.

The layers numbered $\mathrm{v}$-vii in Text-fig. $5, \mathrm{~A}$ and $\mathrm{B}$, constitute the socalled inner testa or seed-coat.

v. A layer, several cells in thickness, of delicate thin-walled tissue which appears totally collapsed and crushed in the ripe seed. The walls of these cells give the pectin reaction with ruthenium red.

vi. A layer of moderately large cells with dense granular contents and large nuclei. In the ripe seed these cells form a very

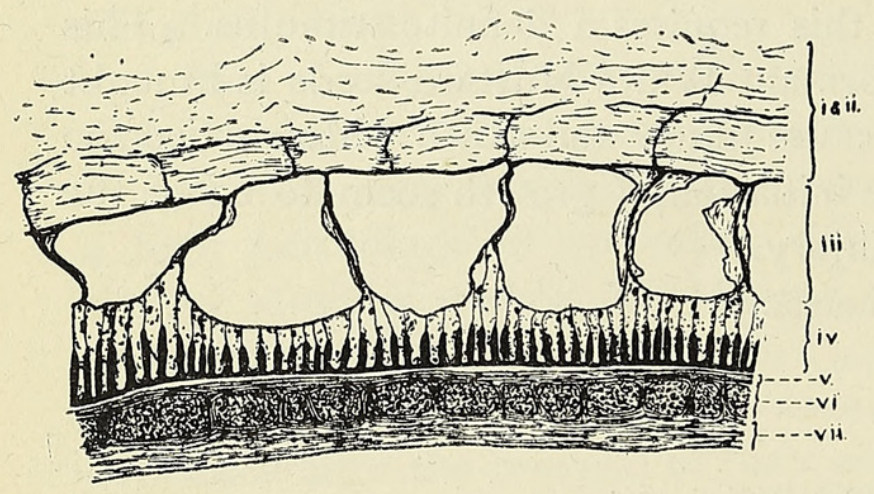

A.

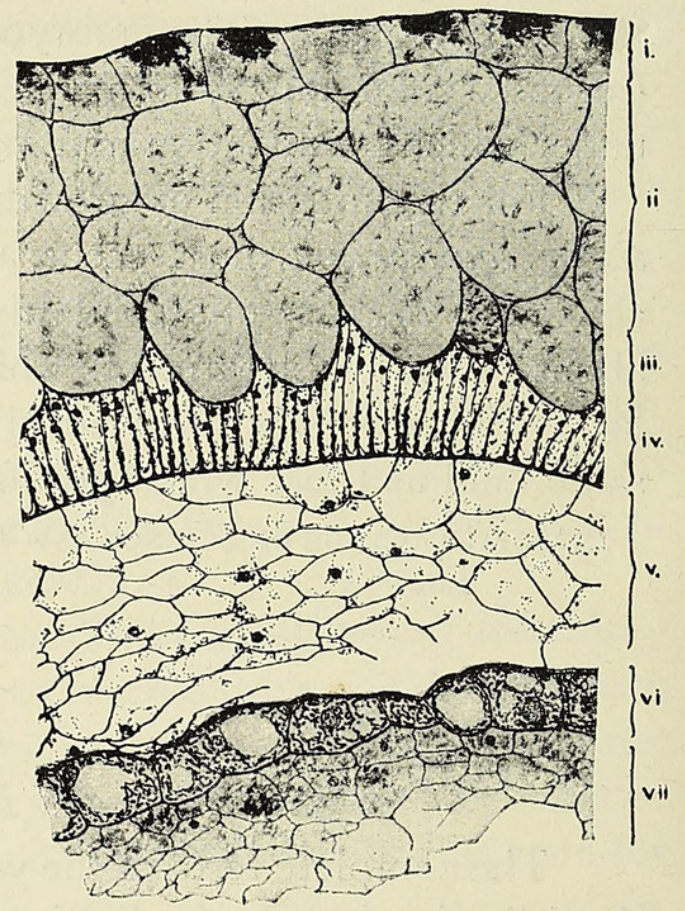

B.

TEXT-FIG. 5 .

characteristic compact layer (Text-fig. 5, A). The walls of these cells give the pectin reaction with ruthenium red and are insoluble in cuprammonia. The cell contents consist of proteid granules and oil.

vii. A layer, many cells in thickness, of delicate tissue, the cells of which appear totally collapsed and crushed in the ripe seed. The walls of these cells give the reactions characteristic of cellulose with congo red and with chlor-zinc-iodide. They do not stain with ruthenium red. Since, however, they are insoluble in cuprammonia, they probably consist of hemicellulose. 


\section{LITERATURE CITED.}

1. KIDn, F.: The Controlling Influence of Carbon Dioxide in the Maturation, Dormancy, and Germination of Seeds. Part I. Roy. Soc. Proc., B., vol. Ixxxvii, I9I4.

2. - The Controlling Influence of Carbon Dioxide in the Maturation, Dormancy, and Germination of Seeds. Part II. Roy. Soc. Proc., B., vol. Ixxxvii, 19I4.

3. Crocker, W.: Mechanics of Dormancy in Seeds. American Journ. of Bot., vol. iii, No. 3, 19r6.

4. KIDD, F.: The Controlling Influence of Carbon Dioxide. Part III. Roy. Soc. Proc., B., vol. lxxxix, 1915 .

5. Crocker, W., and Davis, W. E.: Delayed Germination in Seed of Alisma Plantago. Bot. Gaz., vol. lviii, I9I4.

6. Müller, G.: Beiträge zur Keimungsphysiologie: Untersuchungen über die Sprengung der Samen- und Fruchthüllen bei der Keimung. Pringsh. Jahrb. f. wiss. Bot., Bd. liv, I9r5.

7. Crocker, IV.: Rôle of Seed-coats in Delayed Germination. Bot. Gaz., vol. xlii, I 906.

8. Shull, C. A.: The Oxygen Minimum and the Germination of Xanthium Seeds. Bot. Gaz., vol. lii, I9II.

9. Rose, D. H.: A Study of Delayed Germination in Economic Seeds. Bot. Gaz., vol. lix, I9I 5.

10. Atwoon, W. M.: A Physiological Study of the Germination of Avena fatua. Bot. Gaz., vol. Ivii, I9I4.

11. Eckerson, S. H. : A Physiological and Chemical Study of After-ripening. Bot. Gaz., vol. I9I3.

12. Lehmann, E. : Ueber katalytische Lichtwirkung bei der Samenkeimung. Biochem. Zeitschr., Bd. 1, 1913.

13. Holfert, J. : Die Nährschicht der Samenschalen. Flora, Bd. 1xxiii, I89o.

14. Schroeder, J.: Untersuchung der Samen der Brassica-Arten und Varietäten. Landw. Versuchs-Stationen, Bd. xiv, $187 \mathrm{I}$.

\section{DESCRIPTION OF FIGURES ON PLATE XXIII.}

Illustrating Dr. Kidd and Mr. West's paper on the Controlling Influence of Carbon Dioxide.

Fig. I. A \& B. Eight embryos from dormant seeds photographed four days after removal of the seed-ccats; four ungerminated.

$\mathrm{B}^{2}$. The same four embryos photographed four days later, showing healthy development of the radicle.

Fig. 2. A \& B. Twelve embryos from dormant seeds photographed eight days after removal of the seed-coats; five ungerminated.

$\mathbf{B}^{2}$. The same five embryos photographed three days later; one still ungerminated. 
Annals of Botany.

Fig. 1 .

(Exper. 2, Table XVI.)

A

B ... After 4 days.

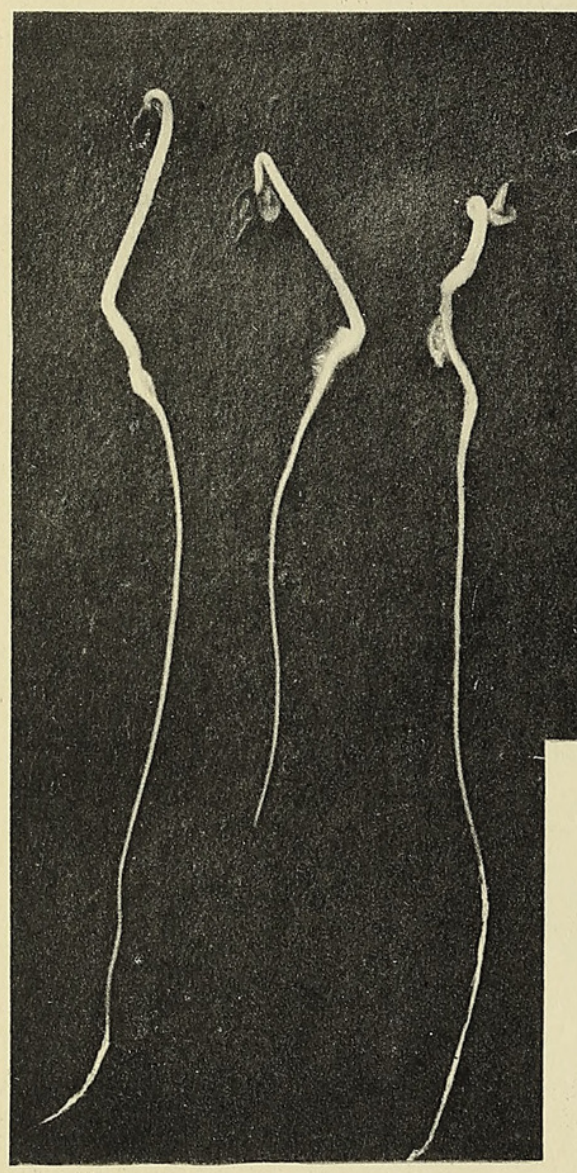

1.8

$\mathrm{B}^{2} \quad 4$ days later.

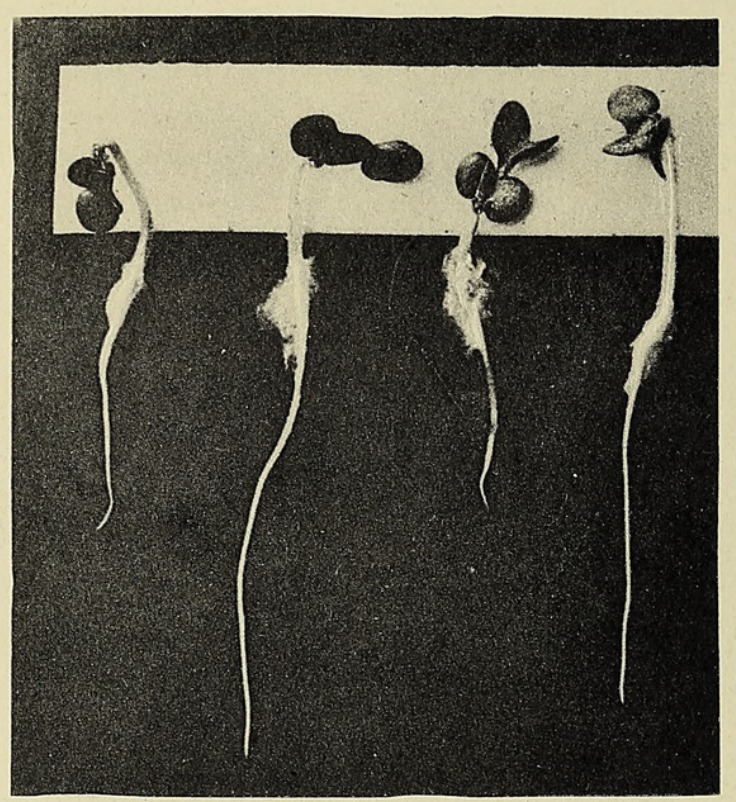

KIDD AND WEST- BRASSICA ALBA. 
Fig. 2 .

(Exper. 5. Table XVI.)

A B A After 8 days.

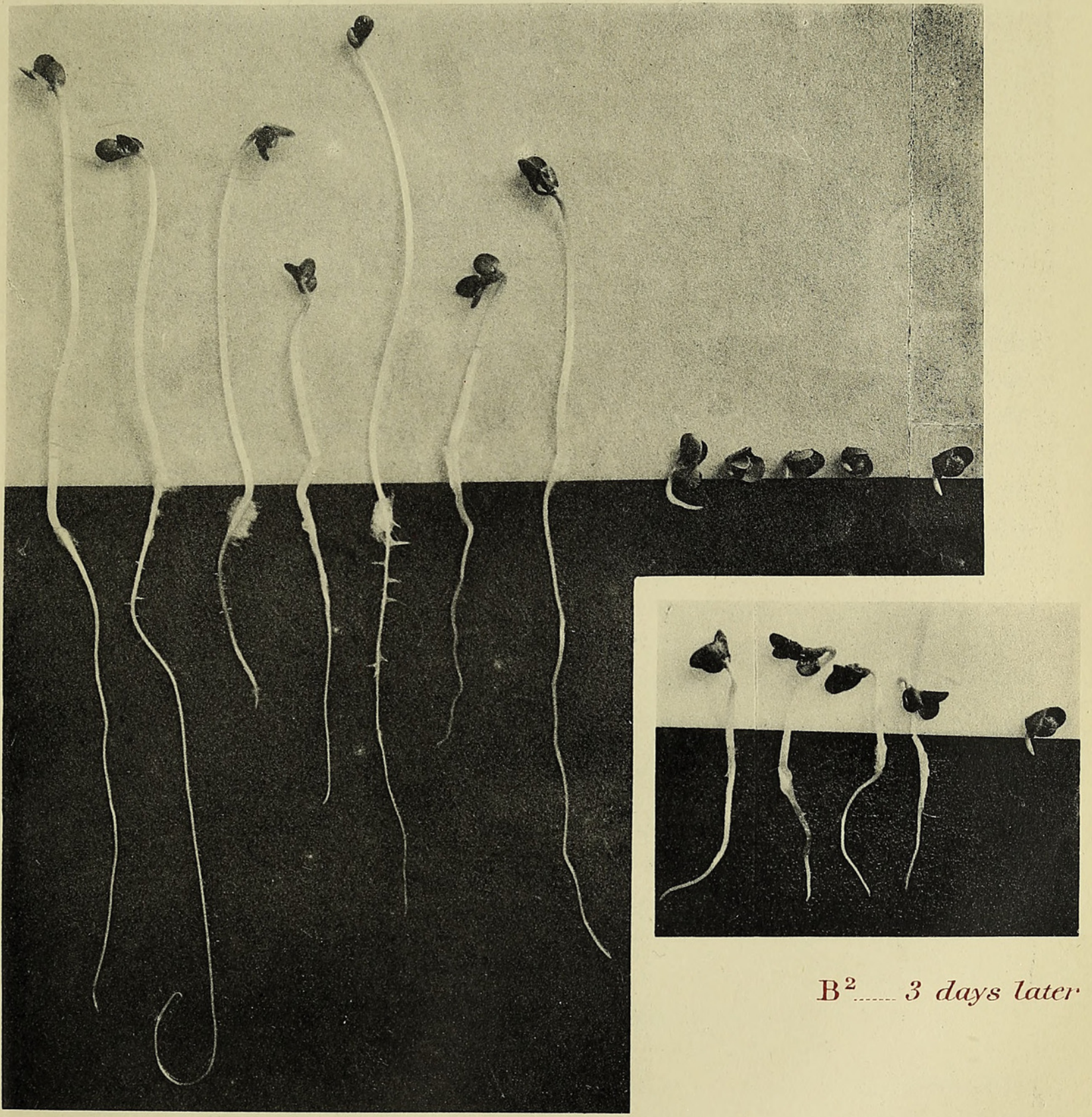




\section{$2 \mathrm{BHL}$ Biodiversity Heritage Library}

Kidd, Franklin. and West, Cyril. 1917. "The controlling influence of carbon dioxide." Annals of botany 31, 457-487. https://doi.org/10.1093/oxfordjournals.aob.a089658.

View This Item Online: https://www.biodiversitylibrary.org/item/232813

DOI: https://doi.org/10.1093/oxfordjournals.aob.a089658

Permalink: https://www.biodiversitylibrary.org/partpdf/320201

\section{Holding Institution}

Smithsonian Libraries

\section{Sponsored by}

Biodiversity Heritage Library

\section{Copyright \& Reuse}

Copyright Status: Not in copyright. The BHL knows of no copyright restrictions on this item.

This document was created from content at the Biodiversity Heritage Library, the world's largest open access digital library for biodiversity literature and archives. Visit BHL at https://www.biodiversitylibrary.org. 